\title{
Structure and Alpha Biodiversity of Major Plant \\ Communities in South Africa, a Close Biogeographical Relation with Australia
}

\author{
Raymond L. Specht (Corresponding author) \\ Emeritus Professor of Botany, The University of Queensland, Brisbane, QLD 4072, \\ Australia \\ E-mail: r.specht@uqconnect.net
}

Eugene J. Moll

Department of Biodiversity and Conservation Biology, University of the Western Cape, Bellville, South Africa

Received: June 30, 2014 Accepted: July 13, $2014 \quad$ Published: October 14, 2014

doi:10.5296/jee.v5i2.6446 URL: http://dx.doi.org/10.5296/jee.v5i2.6446

\begin{abstract}
During the short season of annual shoot growth, Foliage Projective Covers (FPCs) in both overstorey and understorey strata, coupled with leaf attributes (Leaf Specific Weight, Leaf Area), are determined by aerodynamic fluxes flowing over and through the plant community. These parameters determined the Evaporative Coefficient - the monthly ratio of actual to potential evapotranspiration per mm of available soil moisture. Maximal FPC is produced in habitats supplied with optimal soil moisture during this short season of shoot growth.

Vertical growth of foliage shoots - the number of leaves per shoot and internode lengths is determined in relation with available soil water and soil nutrients (especially phosphorus and nitrogen ions) during this seasonal growth. Ambient temperature is similarly concerned.

The Leaf Area Index (area of all leaves per hectare) determines the interception of solar radiation - and hence net photosynthesis per hectare per annum. This energy-fixation by overstorey foliage determines the yearly growth of the producer, consumer and decomposer sections of the ecosystem. In turn, the biodiversity (number of species per hectare) of producers and resident consumers is determined.
\end{abstract}




\section{Macrothink}

Journal of Environment and Ecology

ISSN 2157-6092

2014, Vol. 5, No. 2

Wherever optimal soil water occurred in median-nutrient soils in the coastal subtropical region, closed-forests/scrubs developed containing $131 \pm 11$ species compared with 80-90 species per hectare in nearby open-forests.

Wherever optimal soil water occurred in nutrient-poor soils in the warm temperate region, closed-heathland ( \pm tall proteoid shrubs) vegetation developed containing $90-135$ species per hectare, compared with about 60 species per hectare in nearby open-heathlands.

Keywords: Evaporative coefficient, Foliage projective cover, Alpha biodiversity, Open-communities, Closed-communities, Arid to humid climates 


\section{Introduction}

The study of community-physiological processes was promoted internationally during the International Biological Program (Specht 1967). During the 1970s, David Goodall, then Director of the IBP Desert Biome Centre in Logan, Utah, U.S.A., was invited to compile a 30 volume series on Ecosystems of the World for Elsevier Scientific Publishing Company, Amsterdam (Goodall 1977-2006). Ray Specht was co-opted to compile the volume on Heathlands and Related Shrublands. Vol. 9A. Descriptive Studies. (Specht 1979a) and Vol. 9B. Analytical Studies (Specht 1981a) that develop on nutrient-poor soils throughout the world. Articles on 'The sclerophyllous (heath) vegetation of Australia' (Specht 1979b), 'Heathlands of Western Australia' (George et al. 1979, 1988), 'The vertebrate fauna of Australian heathlands (Kikkawa et al. 1979), 'Seasonal growth and flowering rhythms: Australian heathlands' (Specht et al. 1981), 'Dark Island heathland, South Australia: Faunal rhythms' (Edmonds \& Specht, M. 1981), 'South African heathlands'(Kruger 1979), 'Aspects of vertebrate life in fynbos, South Africa' (Bigalke 1979), 'African mountain heathlands' (Killick 1978, 1979), 'Seasonal growth and flowering rhythms: South African heathlands (Kruger 1981) were included. The Role of Nutrients in Mediterranean-type Ecosystems was expanded in a Stellenbosch meeting of MEDECOS (Kruger et al. 1983).

The plant communities that develop on median-nutrient soils in southern Australia and South Africa were explored in Ecosystems of the World. Vol. 11. Mediterranean-Type Shrublands (di Castri et al. 1981). Articles on 'South African Mediterranean Shrublands' (Boucher \& Moll 1981), 'Mallee ecosystems in Southern Australia' (Specht 1981b), 'Bird communities of the Australian mallee' (Schodde 1981) and 'Structure, pattern and diversity of a mallee community in New South Wales' (Whittaker et al. 1979) contrasted these nutrient-richer plant communities with the nutrient-poor heathlands of South Africa and Australia.

Detailed information on the climate, eco-morphological characteristics, foliar nutrients, species richness, vertebrates and soil/litter invertebrates in 'Mediterranean-type Ecosystems' of the world was collated in 'A Data Source Book' (Specht 1988a).

Information on South African ecosystems north of the Capensis Region was collated in Ecosystems of the World. Vol. 8B. Natural Grasslands (Coupland 1993) and Vol. 12B. Hot Deserts and Arid Shrublands (Evanari et al. 1986).

The compilation of the data for the Mediterranean-type climate of Capensis Region (Specht 1988a) was extended throughout South Africa by the authors of this paper.

\subsection{Biogeographical Relationship of South Africa with Australia}

The broad patterns of the evolution of vascular plants on the southern continents of Gondwanaland were traced in 'Comparative evolution of Mediterranean-type ecosystems: A southern perspective' (Deacon 1983), 'Patterns of Gondwana plant colonisation and diversification' (Anderson et al. 1999) and in 'Southern (Austral) Ecosystems' (Weston \& Hill 2013). Angiosperms appeared in the palynological records during the Mid-Cretaceous, about 100 million years ago. 'The Proteaceae originated in northern Gondwana in Late Cenomanian times and radiated into southern high latitudes by the Turonian. There the family 
underwent substantial differentiation during the Santonian-Maastrichian' — the Late Cretaceous, over 65 million years ago (Dettmann 1999).

Both the Australasian and African Tectonic Plates separated from Antarctica after the Cretaceous, about 65 million years ago (Smith \& Briden 1977) when the climate at the southern part of each continent, at latitude $60^{\circ} \mathrm{S}$, was then subtropical (Specht et al. 1992). Under this subtropical climate, the seasonal shoot growth of the overstorey occurred when mean monthly temperatures ranged from $15^{\circ} \mathrm{C}$ to $25^{\circ} \mathrm{C}$ with a peak at $20^{\circ} \mathrm{C}$ (Specht \& Rayson 1957; Specht \& Brouwer 1975; Hegarty 1990; Specht \& Specht 1999). As both the African and Australasian Tectonic Plates drifted northward from Antarctica - the Australasian Plate at an average rate of $66 \mathrm{~mm}$ per year (Wellman \& McDougall 1974) - the cold Southern Ocean current that had been formed induced cooler weather on the southern part of each Plate - a Mediterranean-type climate with a wet winter-spring alternating with a dry summer season resulted. Today in Australia, elements of the original Gondwanan flora of the south merge with the tropical flora of the north in the subtropical region of south-eastern Queensland and north-eastern New South Wales (Burbidge 1960; Johnson \& Briggs 1981). Examples of the heathland vegetation ( \pm overstorey trees) on nutrient-poor soils, grassland vegetation ( \pm overstorey trees) on median-nutrient soils and closed-forest vegetation in well-watered habitats occur from the tropical north to the temperate south of the continent (Specht 1958a, 1958b, 1981d; Specht \& Specht 1999).

The close biogeographical relationships between South Africa and Australia are studied in this article:

- The nutrient-poor heathland vegetation, on quartzite/sandstone outcrops, as well as on the remnant Gondwanan lateritic soils, with two genera of Cyperaceae and three genera of Restionaceae common with Australia (Table 1 after Kruger 1979);

Table 1. Generic composition of major families in fynbos/heathland vegetation on nutrient-poor soils in Cape Province, South Africa (Sites 1-10 in Appendix III, Kruger 1979, pp. 58-78).

Overstorey - Proteaceae: Leucadendron (Sites 1, 2, 3, 4, 8. 10); Mimetes (Site 3); Protea (Sites 1, 2. 3, 4, 5, 8, 10)

Tall shrublands of Leucospermum cuneiforme and tall closed-scrub of Protea neriifolia occur along drainage lines near ridge crests (Kruger 1979, p. 47).

Understorey - Ericaceae: Aniserica (Site 4); Blaeria (Sites 1, 4, 5); Eremia (Site 1); Erica (Sites 1, 2, 3, 4, 5, 7, 10); Sympieza (Site 3);

Cyperaceae: Chrysothrix (Sites 3, 4, 5); Epischoenus (Site 6); Ficinia (Sites 1, 3, 4, 7, 8, 10); Kobresia (Site 7); *Scirpus (Site 8); *Tetraria (Sites 1, 2, 3, 4, 5, 10);

Restionaceae: Chondropetalum (Sites 3, 4, 6, 10); Elegia (Sites 3, 4, 6, 10); Hypodiscus (Sites 1, 3, 4, 5, 10); *Hypolaena (Site 6); *Leptocarpus (Sites 2, 3, 4); *Restio (Sites 1, 2, 3, 4, 5, 6, 7, 9, 10); Staberoha (Sites 4, 5); Thamnochortus (Sites 2, 3, 4, 10); Willdenowia (Sites $4,5,8)$ 
Genera of Poaceae on marginal, median-nutrient soils $-{ }^{+}$Aira (Site 2); Alloteropsis (Site 7); ${ }^{+}$Andropogon (Site 7); ${ }^{+}$Anthoxanthum (Site 1); Cymbopogon (Sites 2, 9); ${ }^{+}$Ehrharta (Sites 1, 4, 5, 6, 8, 9); *Eragrostis (Sites 2, 7, 8); *Festuca (Site 4); Helictotrichon (Site 2); Lasiochloa (Site 9); Merxmuellera (Sites 1, 3, 4, 5, 9); Pentaschistis (Sites 2, 3, 4, 5, 6, 7, 8); Plagiochloa (Site 2); Pseudopentameris (Site 3); *Themeda (Site 7)

* Genera recorded in both South Africa and southern Australia (Jessop \& Toelken 1986).

+ Genera introduced into southern Australia (Jessop \& Toelken 1986).

- The median-nutrient savanna vegetation, with $15 \mathrm{C} 4$ grass genera common, including the kangaroo-grass, Themeda triandra, and five genera of C3 grasses (Table 2 after Clifford \& Simon 1981; Gibbs Russell et al. 1990; Simon \& Alfonso 2011);

Table 2. Genera of Poaceae recorded in the savannas and grasslands in the Austral Domain of the Sudano-Zambesian Region of South Africa (Gibbs Russell et al. 1990), as well as in Australia (Clifford \& Simon 1981; Simon \& Alfonso 2011)

C4-photosynthetic grass genera: ${ }^{+}$Andropogon, Aristida, Cenchrus, Cymbopogon, Digitaria, Eragrostis, Enneapogon, Elionurus, ${ }^{+}$Ehrharta, Heteropogon, Hyparrhenia, Imperata, Panicum, Setaria, Sporobolus, Themeda, Tragus (Clifford \& Simon 1981; Simon \& Alfonso 2011).

The South African C4 grass genera - Monocymbium, Pogonarthria, Rendlia, Stipagrostis, Trachypogon and Tristachya - are not found in Australia.

C3-photosynthetic grass genera in cooler highland and alpine habitats: Festuca, Microchloa, Oplismenus, Poa and Merxmuellera (allied to Danthonia in Australia)

+ Genera introduced into southern Australia (Clifford \& Simon 1981; Simon \& Alfonso 2011).

- The subtropical closed-forest (rainforest) vegetation of eastern South Africa and eastern Australia, with 35 genera common with Australia (Table 3 after Moll \& White 1978).

Table 3. Generic composition of the closed-forest vegetation in the Indian Ocean Coastal Belt of South Africa (Moll \& White 1978)

Canopy trees - Albizia (Mimosaceae), Brachylaena (Asteraceae), Cassipourea (Rhizophoraceae), *Celtis (Ulmaceae), Chaetachme (Ulmaceae), Chrysophyllum (Sapotaceae), Combretum (Combretaceae), *Croton (Euphorbiaceae), *Drypetes (Euphorbiaceae), *Ficus (Moraceae), *Millettia (Fabaceae), Mimusops (Sapotaceae), *Strychnos (Loganiaceae), Trichilia (Meliaceae), Vepris (Rutaceae).

Canopy trees (infrequent) - Cavacoa (Euphorbiaceae), Cola (Sterculiaceae), *Homalium (Flacourtiaceae), Nuxia (Buddlejaceae), *Phyllanthus (Phyllanthaceae), *Podocarpus (Podocarpaceae), Scolopia (Flacourtiaceae), *Syzygium (Myrtaceae).

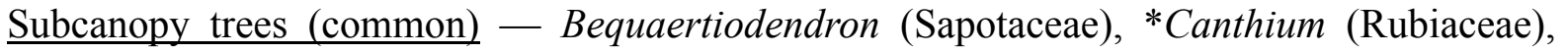


*Clausena (Rutaceae), Dracaena (Dracaenaceae), *Drypetes (Euphorbiaceae), *Erythroxylum (Erythroxylaceae), *Eugenia (Myrtaceae), Memecylon (Melastomaceae), * Pavetta (Rubiaceae), Peddiea (Thymelaeaceae), Teclea (Rutaceae), Tricalysia (Rubiaceae).

Subcanopy trees (less common) - Allophyllus (Sapindaceae), Anastrabe (Scrophulariaceae), Baphia (Leguminosae), Buxus (Buxaceae), *Cryptocarya (Lauraceae), *Diospyros (Ebenaceae), *Gardenia (Rubiaceae), Ochna (Ochnaceae), Oxyanthus (Rubiaceae), Pancovia (Rosaceae), Rawsonia (Flacourtiaceae), Rothmannia (Rubiaceae), Xylotheca (Flacourtiaceae).

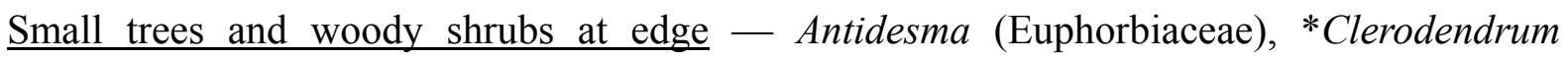
(Lamiaceae), Combretum (Combretaceae), Dichrostachys (Leguminosae), Fagara (Rutaceae), *Grewia (Tiliaceae), Heteropyxis (Malvaceae), Hippobromus (Sapindaceae), Kraussia (Asteraceae), *Maytenus (Celastraceae), Rhus (Anacardiaceae).

Sub-woody plants (2-3 m) at edge - Clutia (Euphorbiaceae), *Euphorbia (Euphorbiaceae), Euryops (Asteraceae), *Hibiscus (Malvaceae), *Leonotis (Lamiaceae), Lippia (Verbenaceae), *Polygala (Polygalaceae), Pseudarthria (Fabaceae), *Solanum (Solanaceae), Syncolostemon (Lamiaceae).

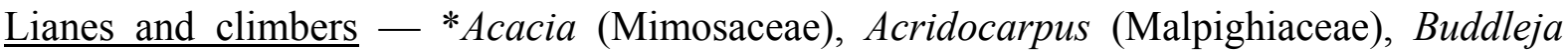
(Buddlejaceae), *Canthium (Rubiaceae), *Capparis (Capparaceae), *Cissus (Vitaceae), Combretum (Combretaceae), Cnestis (Connaraceae), Dalbergia (Fabaceae), *Diospyros (Ebenaceae), Embelia (Myrsinaceae), Entada (Mimosaceae), Monanthotaxis (Annonaceae), Quisqualis (Combretaceae), Oncinotis (Apocynaceae), Putterlickia (Celastraceae), Rhoicissus (Vitaceae), Scutia (Rhamnaceae), *Secamone (Asclepiadaceae), Urera (Urticaceae), Uvaria (Annonaceae).

* Genera recorded in both South Africa and south-eastern Queensland (Stanley \& Ross 1983, 1986); genera Chrysophyllum $\longrightarrow$ Amorphophyllum; Gardenia $\longrightarrow$ Randia and Uvaria $\longrightarrow$ Fitzalania in south-east Queensland.

The structure and species richness of plant communities in South Africa in the biogeographical regions (Figure 1) - Capensis (Taylor 1978; Kruger 1979; Specht \& Moll 1983; Specht et al. 1983); the Austral Domain of the Sudano-Zambesian Region (Werger \& Coetzee 1978); in the closed-forests of the Indian Ocean Coastal Belt (Moll \& White 1978) - are examined in relation to the values predicted by the Australian investigations on community-physiology. 


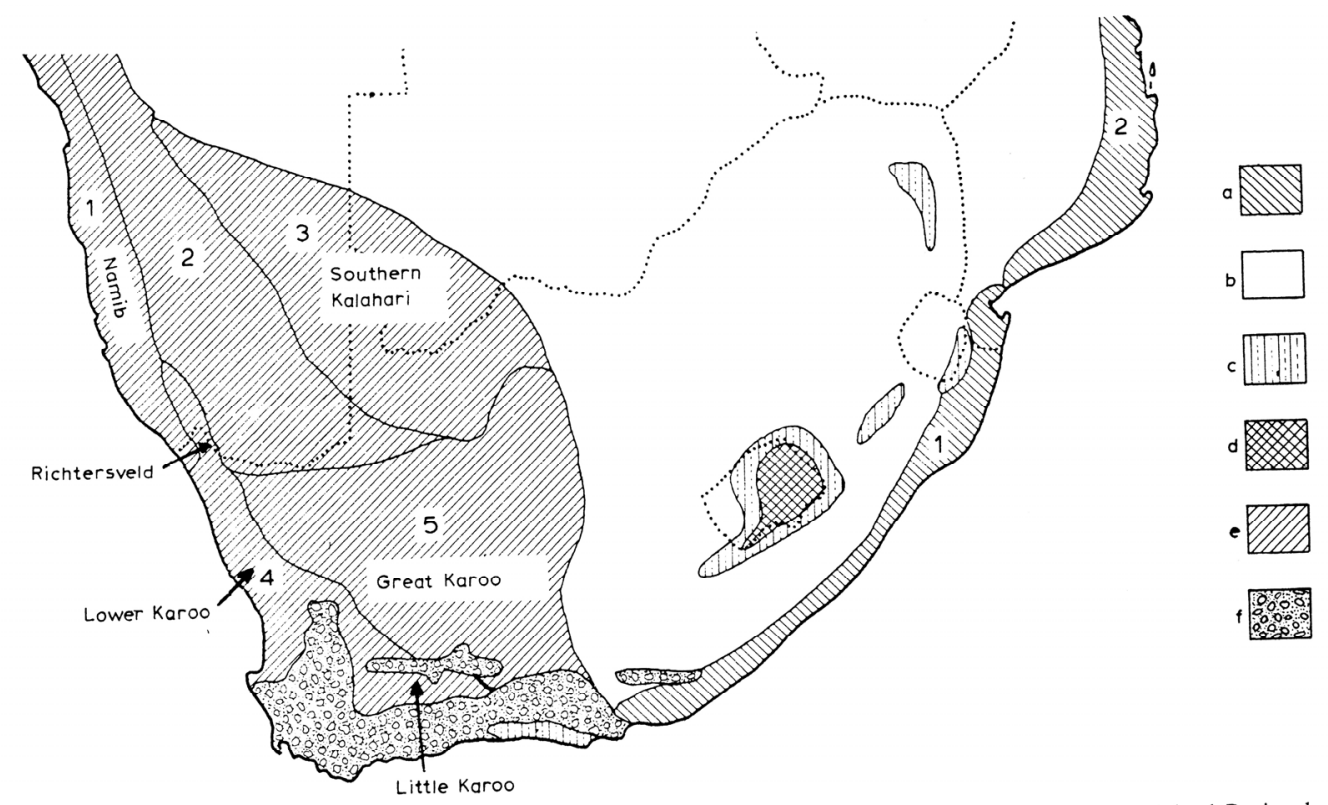

Figure 1. Biogeographical regions in southern Africa (Werger 1986)

$\mathrm{a}=$ Indian Ocean Coastal Belt; $\mathrm{a} 1=$ Tongaland-Pondoland Regional Mosaic; $\mathrm{a} 2=$ Zanzibar-Inhambane Regional Mosaic; $b=$ Zambesian Domain, Sudano-Zambezian Region; $\mathrm{c}=$ Afromontane Region; $\mathrm{d}=$ Austral Domain, Afro-Alpine Region; $\mathrm{e}=$ Karoo-Namib Region; e1 = Namib Domain; e2 = Namaqualand Domain; e3 = Southern Kalahari Subdomain; e4 = Western Cape Domain; e5 = Karoo Domain; $\mathrm{f}=$ Capensis (after Werger 1978a).

The inserted names denote geographical regions.

\section{Methods}

Evaporative Coefficient of each Meteorological Station: The community-physiological constant - the Evaporative Coefficient $(k)$ — of each meteorological site was computed by optimising the monthly rate of usage of soil water so that some water (albeit minimal) is available for evapotranspiration from the evergreen plant community during the driest season of the year (Specht 1972a, 1972b, 1981c; Specht \& Specht 1999).

For every macroclimate, in spite of seasonal and yearly fluctuations in rainfall, the monthly moisture index (M.I.), the ratio of actual to potential evapotranspiration $(E a / E p)$, is correlated with available soil water (W $\mathrm{mm}$ ) by the Evaporative Coefficient $(k)$ - defined by analysis of long-term studies on soil moisture of representative plant communities from the arid to the humid climatic zone (Specht 1957a, 1957b; Martin \& Specht 1962; Carrodus \& Specht 1965; Specht \& Jones 1971; Specht 1972a) as

$$
\text { M.I. }=(E a / E p) \text { equivalent to }(E a / E o)=k W=k(P-R-D-S e x t)
$$

Where $k$ is the Evaporative Coefficient (a community-physiological constant), $E a$ is actual evapotranspiration $(\mathrm{mm}), E p$ is potential evapotranspiration $(\mathrm{mm}), E o$ is pan evaporation $(\mathrm{mm})$, which was estimated using mean maximum temperature and vapour pressure 


\section{Macrothink}

(Fitzpatrick 1963), $P$ is monthly precipitation $(\mathrm{mm}), R$ is monthly runoff $(\mathrm{mm}), D$ is monthly drainage $(\mathrm{mm})$ and Sext is extractable soil water ( $\mathrm{mm}$ at the beginning of the month) between Permanent Wilting Percentage and Field Capacity.

All values of $k$ assess the monthly ratio of actual to potential evapotranspiration per $\mathrm{mm}$ of soil water available during each month. The perhumid climatic zone is defined where $k>$ $0.75 \times 10^{-2}$; the humid climatic zone where $k=0.75-0.55 \times 10^{-2}$; the subhumid climatic zone where $k=0.55-0.45 \times 10^{-2}$; the semiarid climatic zone where $k=0.45-0.35 \times 10^{-2}$; the arid climatic zone where $k<0.35 \times 10^{-2}$ (Figure 2).

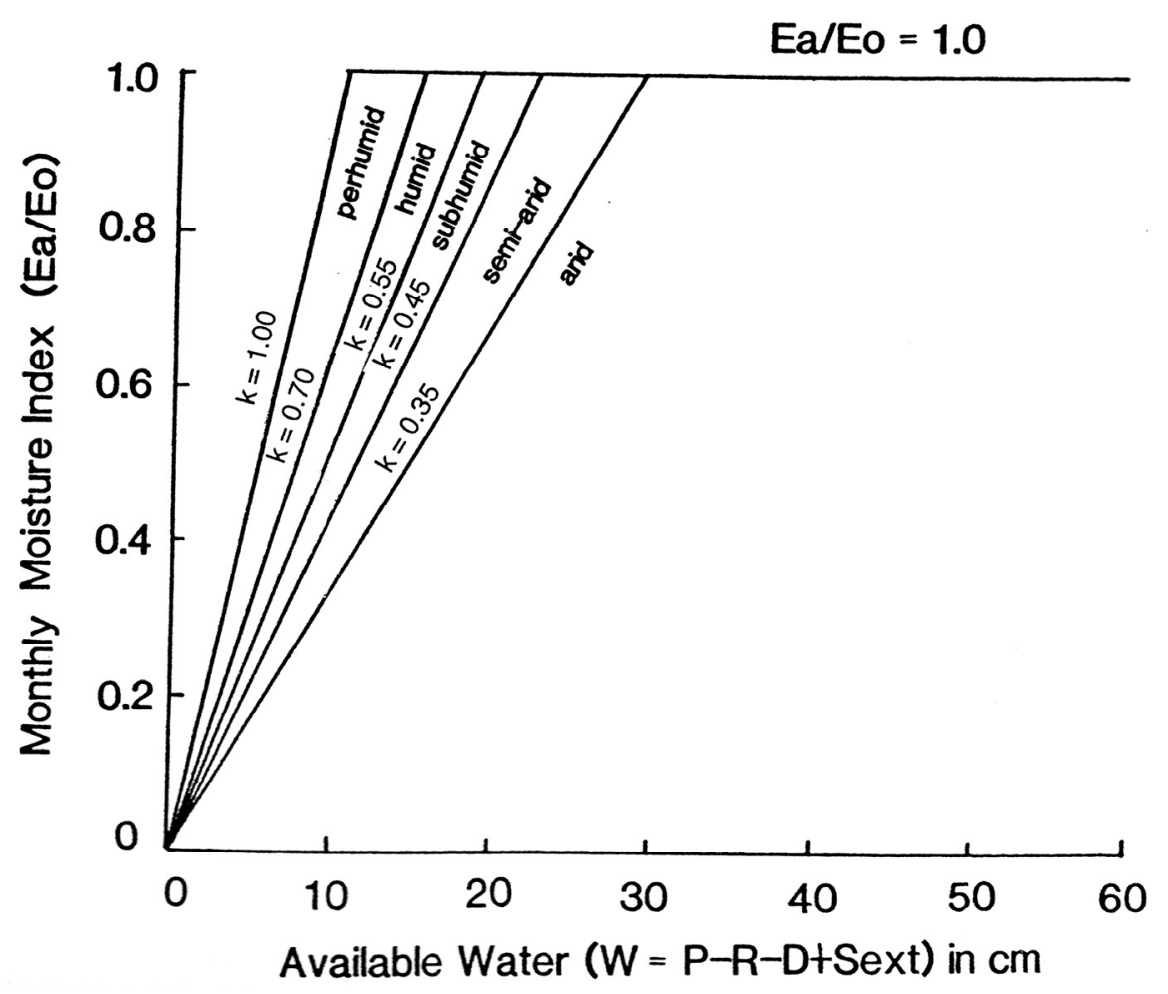

Figure 2. Relationship between Monthly Moisture Index of actual to potential evapotranspiration $(E a / E o)$ and Available Soil Water $(W)$ in perhumid to arid climatic zones. (Specht 1972a)

Range of Evaporative Coefficients $(\mathrm{k})$ in climatic zones - Arid Zone $\left(\mathrm{k}<0.35 \times 10^{-2}\right)$, Semi-arid Zone $\left(\mathrm{k}=0.35-0.45 \times 10^{-2}\right)$, Subhumid Zone $\left(\mathrm{k}=0.45-0.55 \times 10^{-2}\right)$, Humid Zone $(\mathrm{k}=$ $\left.0.55-0.75 \times 10^{-2}\right)$, Perhumid Zone $\left(\mathrm{k}>0.75 \times 10^{-2}\right)$.

Where available soil water $(W)$ is sufficient (or more) for optimal evapotranspiration $(E p)$ during the short period of annual foliage growth, the linear relationship between the Moisture Index (M.I.) and available soil water $(W)$ asymptotes to unity (Figure 2). On soils of median-nutrient to nutrient-rich fertility, a closed-forest (rainforest) or a closed-scrub develops, markedly in contrast to the open-structured plant communities that develop in seasonally-droughted climates; on nutrient-poor soils, a closed-heathland ( \pm tall Proteaceae) develops. 
Seasonal shoot growth and leaf fall: Seasonal shoot growth is measured monthly on tagged shoots of representative overstorey and understorey species in a plant community. Monthly samples of foliage shoots harvested from the canopy of tall overstorey species will reveal the number of new leaves produced, also the number of leaves retained from the previous season of growth. Monthly leaf fall is measured in random litter trays.

Leaf Area and Leaf Specific Weight (dry weight of leaf per unit leaf area) is measured on leaves of foliage shoots harvested at maturity.

Foliage Projective Cover: The horizontal coverage of foliage in a plant community is measured by cross-wire sighting tubes at $50 \mathrm{~cm}$ intervals along randomly-located $50 \mathrm{~m}$ line transects (Specht 1970). The overstorey stratum of trees and tall shrubs (over $2 \mathrm{~m}$ in height) is recorded using upward sighting tubes; the understorey stratum of low shrubs and ground stratum $(<2 \mathrm{~m}$ in height) is recorded using downward sighting tubes.

Satellite imagery of the intensity of red and infrared wavelengths reflected from the vegetation in each pixel will enable the Foliage Projective Cover to be assessed by the Normalised Difference Vegetation Index (NDVI) (Tucker 1979). The NDVI has been used to assess the amount of tree-clearing throughout Queensland from 1988 to 2010 (Queensland Department of Science, Information Technology, Innovation and the Arts 2012).

$$
\text { NDVI }=(\text { infrared }- \text { red }) /(\text { infrared }+ \text { red })
$$

Alpha Biodiversity (species richness - N, number of species per unit area): The biodiversity of vascular plants in the plant community was recorded in random quadrats of increasing area (A) - the Species-Area Curve (Jaccard 1928, Hopkins 1955; Whittaker 1972, 1977).

$$
\mathrm{N}=\mathrm{a} \log _{10} \mathrm{~A}+\mathrm{b}
$$

Increasing quadrat-size of $1 \mathrm{~m}^{2}, 100 \mathrm{~m}^{2}, 500 \mathrm{~m}^{2}$ and $1000 \mathrm{~m}^{2}$ was adopted for the 'Species Richness' section, coordinated by Walt Westman in the 'Mediterranean-type Ecosystems. A Data Source Book' (Specht 1988a). As an even larger quadrat size of one hectare $\left(10,000 \mathrm{~m}^{2}\right)$ ensured maximal assessment of biodiversity in Australian open-structured plant communities (Specht 2012), species richness per hectare was estimated by extrapolating the data from smaller quadrats, using Equation (3).

Smaller 'survey plots' of 25-50 m² (termed relevé by Braun-Blanquet 1932; Long 1974) had been used to assess biodiversity in South African vegetation (Werger 1978b). The total number of species recorded in the random relevés in each plant community provided an estimate of the species richness per hectare.

Species richness of disjunct stands of closed-rainforests: As the growth of foliage at the edges of isolated stands of closed-rainforest is abraded by prevailing winds, the species-area-curve of these stands reaches a maximum at about 100 hectares (Specht, A. 1988; Specht 2007) - far larger than the species-area-curves of open-structured plant communities that asymptote at about a hectare in area or less (Jaccard 1928; Hopkins 1955; Whittaker 1972, 1977; Specht et al. 1990; Specht \& Specht 1999; Specht \& Specht 2010; Specht \& Tyler 2010; Specht 2011). 


\section{Results}

Evaporative Coefficient (k): The Evaporative Coefficient - the relationship between the monthly Moisture Index (the ratio of actual/potential evapotranspiration) and available soil water (Equation 1) - was computed for 102 climatic stations throughout South Africa where long-term meteorological data had been recorded. The dominant and diagnostic plant species that are recorded in Acocks' Veld Types $(1953,1975)$ are tabulated in Table 4, together with the calculated values of the Evaporative Coefficients and estimated Foliage Projective Covers and Species Richness (number of species of plants per hectare).

Table 4. Dominant plant species in Acocks' Veld Types $(1953,1975)$ in South Africa, with the Evaporative Coefficients (k) and estimated Foliage Projective Covers (FPC \%) and species richness (SR, number of species per hectare) of each Veld Type.

Range of Evaporative Coefficients $(\mathrm{k})$ in climatic zones - Arid Zone $\left(\mathrm{k}<0.35 \times 10^{-2}\right)$, Semi-arid Zone $\left(\mathrm{k}=0.35-0.45 \times 10^{-2}\right)$, Subhumid Zone $\left(\mathrm{k}=0.45-0.55 \times 10^{-2}\right)$, Humid Zone $(\mathrm{k}$ $\left.=0.55-0.75 \times 10^{-2}\right)$, Perhumid Zone $\left(\mathrm{k}>0.75 \times 10^{-2}\right)$.

\begin{tabular}{|c|c|c|c|c|c|}
\hline $\begin{array}{l}\text { Acocks' Veld } \\
\text { Type }\end{array}$ & Dominant plant species & Diagnostic species & $\begin{array}{c}\text { Evaporative } \\
\text { Coefficient } \\
\left(k \times 10^{-2}\right)\end{array}$ & $\begin{array}{c}\text { FPC \% } \\
\text { (estimated) }\end{array}$ & $\begin{array}{c}\text { SR } \\
\text { (estimated) }\end{array}$ \\
\hline \multicolumn{6}{|l|}{$\begin{array}{l}\text { Tropical Arid } \\
\text { Zone }\end{array}$} \\
\hline $\begin{array}{l}\text { Orange River } \\
\text { Broken Veld }\end{array}$ & $\begin{array}{l}\text { Trees and large } \\
\text { shrubs: Mimosaceae (Acacia), } \\
\text { Anacardiaceae (Searsia). Small } \\
\text { shrubs: Asteraceae (Chrysocoma, } \\
\text { Eriocephalus, Euryops), \& } \\
\text { understorey: Poaceae (Aristida, } \\
\text { Digitaria, Cenchrus) }\end{array}$ & $\begin{array}{l}\text { Aloe dichotoma } \\
\text { (Asphodelaceae) \& } \\
\text { Euphorbia avasmontana } \\
\text { (Euphorbiaceae) }\end{array}$ & $0.22(5)^{*}$ & $(14=22=36)$ & $(6+13=19)$ \\
\hline \multicolumn{6}{|c|}{$\begin{array}{l}\text { Subtropical Arid } \\
\text { Zone }\end{array}$} \\
\hline $\begin{array}{l}\text { Kalahari } \\
\text { Thornveld }\end{array}$ & $\begin{array}{l}\text { Trees: Mimosaceae (Acacia), } \\
\text { Asteraceae (Tarchonanthus). } \\
\text { Shrubs: Mimosaceae } \\
\text { (Dichrostachys), Malvaceae } \\
\text { (Grewia). Understorey: Poaceae } \\
\text { (Stipagrostis, Aristida, Eragrostis, } \\
\text { Tragus, Pogonarthria), } \\
\text { Sterculiaceae (Hermannia) }\end{array}$ & $\begin{array}{l}\text { Acacia erioloba and } A . \\
\text { haematoxylon } \\
\text { (Mimosaceae) }\end{array}$ & $0.30(5)$ & $(22+28=50)$ & $(4+25=29)$ \\
\hline \multicolumn{6}{|l|}{ Karoo } \\
\hline - Arid Karoo & $\begin{array}{l}\text { Chenopodiaceae (Salsola), } \\
\text { Asteraceae (Pentzia, Eriocephalus, } \\
\text { Pteronia), Bignoniaceae } \\
\text { (Rhigozum) \& Poaceae } \\
\text { (Stipagrostis, Enneapogon) and } \\
\text { many annuals in many families and } \\
\text { genera (Aizoaceae, Iridaceae, } \\
\text { Asteraceae, Fabaceae) }\end{array}$ & $\begin{array}{l}\text { Salsola aphylla } \\
\text { (Chenopodiaceae) in } \\
\text { alluvium \& Rhigozum } \\
\text { trichotomum } \\
\text { (Bignoniaceae) and in } \\
\text { calcareous country } \\
\text { Lycium spp. } \\
\text { (Solanaceae), Salsola } \\
\text { spp. \& Stipagrostis spp. } \\
\text { (Poaceae) }\end{array}$ & $0.22(2)$ & $(14+22=36)$ & $(6+13=19)$ \\
\hline Central Upper & Shrubs: Asteraceae (such as & On mountains & $0.26(2)$ & $(18+25=43)$ & $(3+23=26)$ \\
\hline
\end{tabular}




\begin{tabular}{|c|c|c|c|c|c|}
\hline Karoo & $\begin{array}{l}\text { Eriocephalus, Pentzia, Pteronia, } \\
\text { Felicia, Rosenia), Aizoaceae } \\
\text { (Plinthus, Tetragonia) Rubiaceae } \\
\text { (Nenax) \& Poaceae (Eragrostis, } \\
\text { Aristida, Sporobolus, Panicum) }\end{array}$ & $\begin{array}{l}\text { Merxmuelleri (Poaceae) } \\
\text { \& Searsia } \\
\text { (Anacardiaceae), } \\
\text { on flats Eriocephalus } \\
\text { (Asteraceae) \& } \\
\text { Eberlanzia (Aizoaceae) }\end{array}$ & & & \\
\hline $\begin{array}{c}\text { False Upper } \\
\text { Karoo }\end{array}$ & $\begin{array}{l}\text { Shrubs: Asteraceae (Chrysocoma, } \\
\text { Pentzia), Poaceae (Aristida, } \\
\text { Eragrostis, Themeda) \& Iridaceae } \\
\text { (Homeria) }\end{array}$ & $\begin{array}{l}\text { On hills Searsia erosa } \\
\text { (Anacardiaceae) \& } \\
\text { Tetrachne (Poaceae) }\end{array}$ & $0.30(6)$ & $(22+28=50)$ & $(4+25=29)$ \\
\hline Noorsveld & $\begin{array}{l}\text { Shrubs: Bignoniaceae (Rhigozum), } \\
\text { Malvaceae (Grewia), Celastraceae } \\
\text { (Gymnosporia) \& Poaceae } \\
\text { (Eragrostis, Aristida, Cenchrus) }\end{array}$ & $\begin{array}{l}\text { Euphorbia coerulescens } \\
\text { (Euphorbiaceae) }\end{array}$ & $0.33(1)$ & $(25+29=54)$ & $(5+27=32)$ \\
\hline \multicolumn{6}{|l|}{$\begin{array}{l}\text { Subtropical } \\
\text { Semi-arid Zone }\end{array}$} \\
\hline Bankenveld & $\begin{array}{l}\text { Poaceae (Eragrostis, Digitaria, } \\
\text { Setaria, Heteropogon) }\end{array}$ & $\begin{array}{l}\text { Acacia caffra } \\
\text { (Mimosaceae) }\end{array}$ & $0.39(3)$ & $(30+33=63)$ & $(6+32=38)$ \\
\hline $\begin{array}{l}\text { Cymbopogon- } \\
\text { Themeda Veld }\end{array}$ & $\begin{array}{l}\text { Poaceae (Themeda, Eragrostis, } \\
\text { Microchloa,Aristida, Cymbopogon), } \\
\text { Oxalidaceae (Oxalis) \& Asteraceae } \\
\text { (Gazania, Osteospermum, } \\
\text { Helichrysum) \& on hillsides } \\
\text { Mimosaceae (Acacia), Malvaceae } \\
(\text { Grewia })\end{array}$ & $\begin{array}{l}\text { Cymbopogon plurinodis } \\
\text { \& Themeda triandra } \\
\text { (Poaceae) }\end{array}$ & $0.39(3)$ & $(30+33=63)$ & $(6+32=38)$ \\
\hline Ngongoni Veld & $\begin{array}{l}\text { Poaceae (Aristida, Themeda, } \\
\text { Monocymbium, Trachypogon, } \\
\text { Tristachya) and many forb spp. } \\
\text { Forest with Myrsinaceae } \\
\text { (Rapanea), Lauraceae } \\
\text { (Cryptocarya), Myrtaceae } \\
\text { (Syzygium) }\end{array}$ & $\begin{array}{l}\text { Aristida junciformis } \\
\text { grassland (Poaceae) with } \\
\text { rain forest in ravines and } \\
\text { on cool slopes }\end{array}$ & $0.44(1)$ & $(36+36=72)$ & $(8+36=44)$ \\
\hline Valley Bushveld & $\begin{array}{l}\text { Trees and large } \\
\text { shrubs: Euphorbiaceae (Euphorbia), } \\
\text { Mimosaceae (Acacia), smaller } \\
\text { shrubs Rubiaceae (Coddia), } \\
\text { Asphodelaceae (Aloe), Oleaceae } \\
\text { (Jasminum), Acanthaceae (many } \\
\text { genera \& spp.), Poaceae (Panicum, } \\
\text { Sporobolus) }\end{array}$ & $\begin{array}{l}\text { Acacia } \text { spp. } \\
\text { (Mimosaceae) } \\
\text { Euphorbia } \text { spp. } \\
\text { (Euphorbiaceae) and } \\
\text { spp. of Acanthaceae }\end{array}$ & $0.39(1)$ & $(30+33=63)$ & $(6+32=38)$ \\
\hline \multicolumn{6}{|l|}{$\begin{array}{l}\text { Subtropical } \\
\text { Subhumid Zone } \\
\end{array}$} \\
\hline Coastal Forest & $\begin{array}{l}\text { Forest trees: Fabaceae (Millettia, } \\
\text { Erythrina), Anacardiaceae } \\
\text { (Protorhus), Asteraceae } \\
(\text { Brachylaena), Strelitziaceae } \\
\text { (Strelitzia). Shrubs and climbers } \\
\text { Annonaceae (Uvaria), Fabaceae } \\
(\text { Dalbergia }), \text { Rubiaceae (Tricalysia, } \\
\text { Isoglossa). Understorey Poaceae } \\
(\text { Oplismenus) }\end{array}$ & $\begin{array}{l}\text { Many spp. (see opposite } \\
\text { for genera) and in } \\
\text { between Acacia } \text { spp. and } \\
\text { grasses }\end{array}$ & $0.49(3)$ & $(41+39=80)$ & $(10+40=50)$ \\
\hline Natal Mist-belt & $\begin{array}{l}\text { Trees: Podocarpaceae } \\
\text { (Podocarpus), Myrsinaceae }\end{array}$ & $\begin{array}{l}\text { Podocarpus } \\
\text { (Podocarpaceae), }\end{array}$ & $0.57(1)$ & $(49+43=92)$ & $(14+49=63)$ \\
\hline
\end{tabular}




\begin{tabular}{|c|c|c|c|c|c|}
\hline & $\begin{array}{l}\text { (Rapanea), Lauraceae } \\
\text { (Cryptocarya), Ulmaceae (Celtis) }\end{array}$ & Xymalos (Monimiaceae) & & & \\
\hline $\begin{array}{l}\text { Sourveld } \\
\text { Highland } \\
\text { Sourveld }\end{array}$ & $\begin{array}{l}\text { Poaceae (Themeda, Trachypogon, } \\
\text { Tristachya, Monocymbium, } \\
\text { Rendlia) and many forbs in the } \\
\text { Asteraceae, Fabaceae, Rubiaceae, } \\
\text { Iridaceae, Orchidaceae, etc. }\end{array}$ & $\begin{array}{l}\text { Many grasses and low } \\
\text { forbs all to } \sim 1 \mathrm{~m} .\end{array}$ & $0.54(2)$ & $(46+42=88)$ & $(12+46=58)$ \\
\hline $\begin{array}{l}\text { Sourveld } \\
\text { Piet Retief } \\
\text { Sourveld }\end{array}$ & $\begin{array}{l}\text { Poaceae (Tristachya, Themeda, } \\
\text { Rendlia, Eragrostis, Andropogon), } \\
\text { Asteraceae (Berkheya) }\end{array}$ & $\begin{array}{l}\text { Grassland with scrub on } \\
\text { rocky slopes with } \\
\text { Leucosidea (Rosaceae) } \\
\text { and Scolopia } \\
\text { (Salicaceae) and some } \\
\text { scattered Protea } \\
\text { roupelliae (Proteaceae) }\end{array}$ & $0.56(2)$ & $(47+42=89)$ & $(13+48=61)$ \\
\hline Thornveld & $\begin{array}{l}\text { Mimosaceae (Acacia, } \\
\text { Dichrostachys) \& Poaceae } \\
\text { (Themeda, Diheteropogon, } \\
\text { Imperata, Digitaria) }\end{array}$ & Acacia and grasses & & & \\
\hline False Thornveld & $\begin{array}{l}\text { Poaceae (Sporobolus, Digitaria, } \\
\text { Eragrostis, Cymbopogon, } \\
\text { Themeda). Shrubs are Celastraceae } \\
\text { (Gymnosporia), Boraginaceae } \\
(\text { Ehretia), Apocynaceae (Carissa) }\end{array}$ & $\begin{array}{l}\text { Acacia karoo } \\
\text { (Mimosaceae) } \\
\text { dominated with mixed } \\
\text { grasses }\end{array}$ & $0.48(1)$ & $(39+39=78)$ & $(10+40=50)$ \\
\hline $\begin{array}{l}\text { Zululand } \\
\text { Thornveld }\end{array}$ & $\begin{array}{l}\text { Poaceae (Stipagrostis, Ehrharta, } \\
\text { Diheteropogon, Aristida, Themeda), } \\
\text { Cyperaceae (Ficinia), Asteraceae } \\
\text { (Metalasia) }\end{array}$ & $\begin{array}{l}\text { Acacia } \text { and Asteraceae } \\
\text { and Imperata cylindrica } \\
\text { (Poaceae) }\end{array}$ & $0.46(1)$ & $(38+37=75)$ & $(8+38=46)$ \\
\hline Valley Bushveld & $\begin{array}{l}\text { Mimosaceae (Acacia), } \\
\text { Anacardiaceae (Searsia), Oleaceae } \\
\text { (Olea), Celastraceae (Cassine), } \\
\text { Sapotaceae (Sideroxylon) }\end{array}$ & $\begin{array}{l}\text { Acacia } \text { and broad-leaved } \\
\text { small trees }\end{array}$ & $0.48(5)$ & $(39+39=78)$ & $(10+40=50)$ \\
\hline \multicolumn{6}{|l|}{$\begin{array}{l}\text { Warm Temperate } \\
\text { Arid Zone }\end{array}$} \\
\hline $\begin{array}{l}\text { Fynbos } \\
\text { (Heathland) } \\
\text { variants }\end{array}$ & Proteaceae, Ericaceae, Restionaceae & & $0.31(2)$ & $(23+29=51)$ & $(2+41=43)$ \\
\hline $\begin{array}{l}\text { Namaqualand } \\
\text { Broken Veld }\end{array}$ & $\begin{array}{l}\text { Aizoaceae (Galenia, Ruschia, } \\
\text { Eberlanzia, Tetragonia), } \\
\text { Euphorbiaceae (Euphorbia), } \\
\text { Asteraceae (Pteronia), Crassulaceae } \\
\text { (Crassula) }\end{array}$ & $\begin{array}{l}\text { Aloe dichotoma and } \\
\text { many spp. of dwarf } \\
\text { succulents in the } \\
\text { Aizoaceae (no } E \text {. } \\
\text { avasmontana) }\end{array}$ & $0.22(3)$ & $(14+22=36)$ & $(3+21=24)$ \\
\hline $\begin{array}{l}\text { Renosterbosveld } \\
\text { - Coastal }\end{array}$ & $\begin{array}{l}\text { Asteraceae (Elytropappus, } \\
\text { Eriocephalus, Helichrysum, } \\
\text { Athanasia), Scrophulariaceae } \\
\text { (Selago) Fabaceae (Aspalathus) } \\
\text { Polygalaceae (Muraltia), } \\
\text { Crassulaceae (Tylecodon) }\end{array}$ & $\begin{array}{l}\text { Elytropappus } \\
\text { rhinocerotis sometimes } \\
\text { with Olea europaea, } \\
\text { Gymnosporia on rocky } \\
\text { outcrops and heuweltjies }\end{array}$ & $0.24(1)$ & $(16+24=40)$ & $(2+33=35)$ \\
\hline $\begin{array}{l}\text { Renosterbosveld } \\
\text { - Mountain }\end{array}$ & $\begin{array}{l}\text { Asteraceae (Elytropappus, } \\
\text { Relhania, Eriocephalus, Euryops, } \\
\text { Pteronia), Poaceae (Merxmuellera), } \\
\text { Aizoaceae (Galenia) }\end{array}$ & $\begin{array}{l}\text { Elytropappus } \\
\text { rhinocerotis - seemingly } \\
\text { monospecific from afar }\end{array}$ & $0.30(3)$ & $(22+28=50)$ & $(2+39=41)$ \\
\hline Succulent Karoo & $\begin{array}{l}\text { Aizoaceae (Ruschia, } \\
\text { Drosanthemum, Lampranthus, } \\
\text { Galenia, Sphalmanthus) }\end{array}$ & $\begin{array}{l}\text { Many small succulent } \\
\text { spp. in the Aizoaceae } \\
\text { and Asteraceae - some }\end{array}$ & $0.30(4)$ & $(22+28=50)$ & $(2+39=41)$ \\
\hline
\end{tabular}




\begin{tabular}{|c|c|c|c|c|c|}
\hline & $\begin{array}{l}\text { Euphorbiaceae (Euphorbia), } \\
\text { Crassulaceae (Tylecodon, } \\
\text { Crassula), Geraniaceae } \\
\text { (Pelargonium) }\end{array}$ & Crassulaceae too. & & & \\
\hline \multicolumn{6}{|l|}{$\begin{array}{l}\text { WarmTemperate } \\
\text { Semi-arid Zone }\end{array}$} \\
\hline Alexandria Forest & $\begin{array}{l}\text { Celastraceae (Cassine, Maytenus), } \\
\text { Asteraceae (Brachylaena), } \\
\text { Anacardiaceae (Searsia), } \\
\text { Ebenaceae (Diospyros, Euclea) }\end{array}$ & & $0.37(1)$ & $(29+31=60)$ & $(3+43=46)$ \\
\hline Fynbos (variants) & $\begin{array}{l}\text { Proteaceae, Asteraceae, } \\
\text { Restionaceae }\end{array}$ & & $0.41(2)$ & $(33+34=67)$ & $(3+45=48)$ \\
\hline $\begin{array}{l}\text { Themeda- } \\
\text { Festuca Alpine } \\
\text { Veld }\end{array}$ & $\begin{array}{l}\text { Poaceae (Elionurus, Heteropogon, } \\
\text { Eragrostis, Festuca, Merxmuelleri, } \\
\text { Poa), Buddlejaceae (Buddleja), } \\
\text { Rosaceae (Leucosidea) }\end{array}$ & & $0.43(2)$ & $(34+35=69)$ & $(3+46=49)$ \\
\hline \multicolumn{6}{|l|}{$\begin{array}{l}\text { WarmTemperate } \\
\text { Subhumid Zone }\end{array}$} \\
\hline Alexandria Forest & $\begin{array}{l}\text { Ochnaceae (Ochna), Icacinaceae } \\
\text { (Apodytes), Fabaceae (Erythrina), } \\
\text { Podocarpaceae (Podocarpus), } \\
\text { Sapotaceae (Sideroxylon) }\end{array}$ & & $0.37(1)$ & $(29+31=60)$ & $(3+43=46)$ \\
\hline Fynbos (variants) & Proteaceae, Ericaceae, Restionaceae & & $0.41(2)$ & $(33+34=67)$ & $(3+45=48)$ \\
\hline $\begin{array}{l}\text { Cymbopogon - } \\
\text { Themeda Veld }\end{array}$ & Poaceae (Cymbopogon, Themeda) & & $0.43(2)$ & $(34+35=69)$ & $(3+46=49)$ \\
\hline \multicolumn{6}{|l|}{$\begin{array}{l}\text { WarmTemperate } \\
\text { Humid Zone }\end{array}$} \\
\hline Fynbos (variants) & Proteaceae, Ericaceae, Restionaceae & & $0.57(1)$ & $(49+43=92)$ & $(4+49=53)$ \\
\hline Closed-fynbos & $\begin{array}{l}\text { Ericaceae with many Asteraceae } \\
\text { (Athanasia \& others) }\end{array}$ & & $0.71 / 0.98(1)$ & $(89+68=157)$ & $\sim 70 \mathrm{spp}$ \\
\hline $\begin{array}{l}\text { Coastal } \\
\text { Renosterbosveld }\end{array}$ & $\begin{array}{l}\text { Asteraceae (Elytropappus, } \\
\text { Eriocephalus, Helichrysum, } \\
\text { Athanasia), Scrophulariaceae } \\
\text { (Selago), Fabaceae (Aspalathus), } \\
\text { Polygalaceae (Muraltia) and } \\
\text { Poaceae (Themeda, Hyparrhenia) } \\
\text { with Mimosaceae in ravines } \\
\text { (Acacia) }\end{array}$ & $\begin{array}{l}\text { Elytropappus } \\
\text { rhinocerotis } \\
\text { Before European } \\
\text { settlement - } \\
\text { Tall shrubs: Olea } \\
\text { europaea subsp. } \\
\text { africana (Oleaceae), } \\
\text { Sideroxylon inerme } \\
\text { (Sapotaceae), } \\
\text { Euclea undulata } \\
\text { (Ebenaceae). } \\
\text { Poaceae (Themeda } \\
\text { triandra. Eragrostis } \\
\text { curvula) } \\
\text { (Boucher \& Moll 1981) }\end{array}$ & $0.57(1)$ & $(49+43=92)$ & $(4+49=53)$ \\
\hline Knysna Forest & $\begin{array}{l}\text { Oleaceae (Olea), Lauraceae } \\
\text { (Ocotea), Podocarpaceae } \\
\text { (Podocarpus), Apocynaceae } \\
\text { (Gonioma), Hamamelidaceae } \\
\text { (Trichocladus) }\end{array}$ & & $0.61 / 0.98(1)$ & $(89+68=157)$ & 71 spp. \\
\hline $\begin{array}{l}\text { North East Sandy } \\
\text { Highveld }\end{array}$ & $\begin{array}{l}\text { Poaceae (Tristachya, Trachypogon, } \\
\text { Themeda, Heteropogon, }\end{array}$ & & $0.56(1)$ & $(47+42=89)$ & $(4+48=52)$ \\
\hline
\end{tabular}


* Number of Meteorological Stations in brackets

Values of the Evaporative Coefficient range from over $0.5 \times 10^{-2}$ in humid pockets and highlands around the southern and eastern coast but decrease rapidly inland to semi-arid and arid climates where the Evaporative Coefficient declines to less than $0.2 \times 10^{-2}$ (Figure 3)

Maximum soil water storage during the wettest month of the year was estimated for each meteorological station. As most of the soils in the region are shallow, the extra soil moisture is lost as drainage. In localities where rainfall is high, this excess water drains down gullies and may pond in basins where sub-soil moisture may still be high during the summer season of foliage shoot growth; a closed-structured plant community then results.

The subtropical region was defined with mean annual temperatures between $20-30^{\circ} \mathrm{C}$ (with summer rainfall). In southern South Africa, the warm temperate region (with winter-spring rainfall and a dry summer season) has mean annual temperatures between $10-20^{\circ} \mathrm{C}$ in a Mediterranean-type climate (Figure 3).

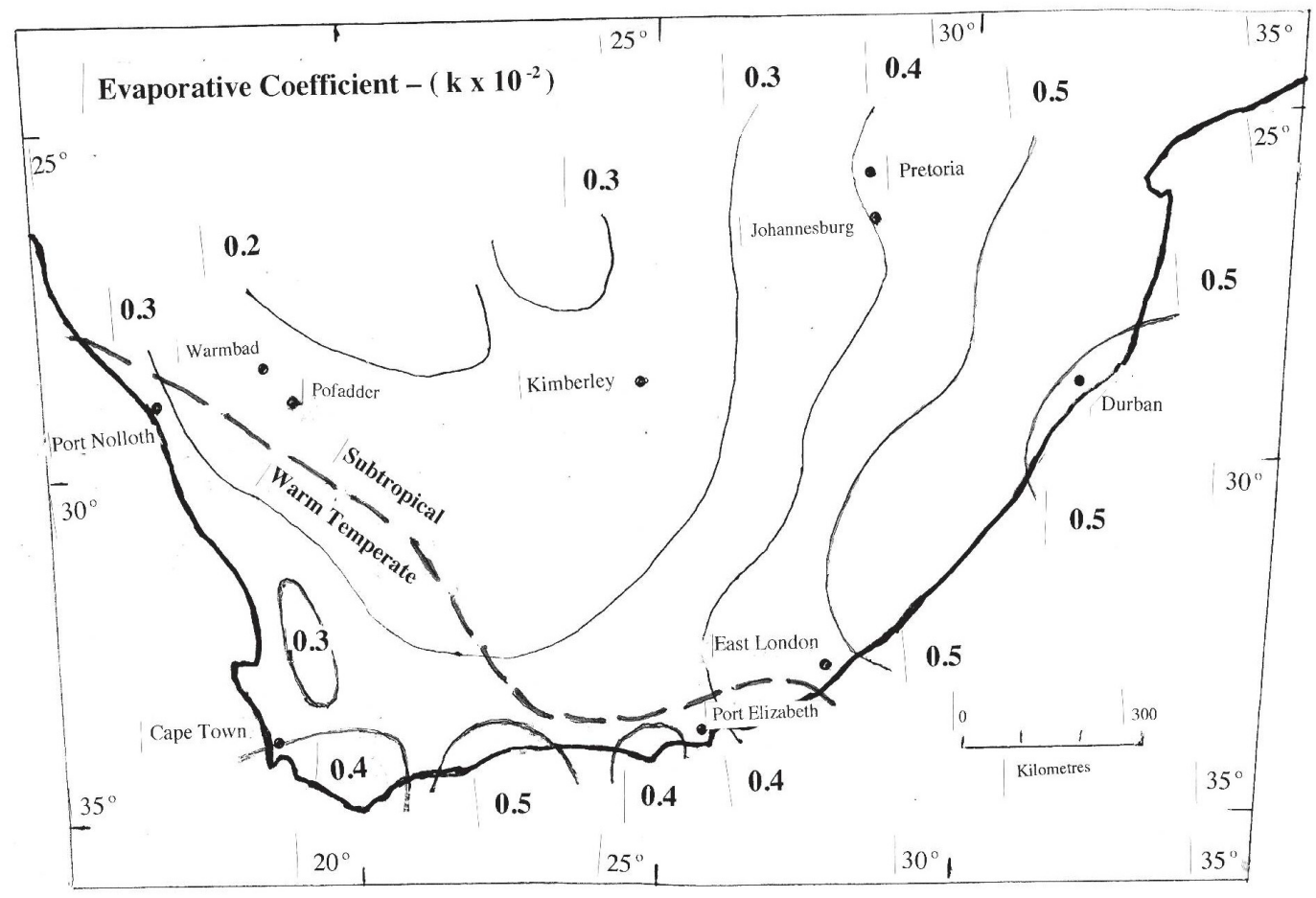

Figure 3. Isolines of the Evaporative Coefficient ( $k$, monthly ratio of actual to potential evapotranspiration per mm available soil water) of meteorological sites in South Africa

Range of Evaporative Coefficients $(\mathrm{k})$ in climatic zones - Arid Zone $\left(\mathrm{k}<0.35 \times 10^{-2}\right)$, Semi-arid Zone ( $\mathrm{k}$ $\left.=0.35-0.45 \times 10^{-2}\right)$, Subhumid Zone $\left(\mathrm{k}=0.45-0.55 \times 10^{-2}\right)$, Humid Zone $\left(\mathrm{k}=0.55-0.75 \times 10^{-2}\right)$, Perhumid Zone $\left(\mathrm{k}>0.75 \times 10^{-2}\right)$.

Seasonal shoot growth and leaf fall: The seasonal foliage shoot growth of Proteaceae in the overstorey of Cape Fynbos Heathland vegetation growing on nutrient-poor soils in the 


\section{Macrothink}

Capensis Region of South Africa occurs during late spring through summer - the driest season of the year (Figure 4); shoot growth in Ericaceae and Restionaceae in the understorey occurs during late winter through spring. On moderately leached soils, the original overstorey survivors of the Renosterveld (Boucher \& Moll 1981; Bergh et al. 2014) - tall shrubs such as Olea europaea subsp. africana (Oleaceae), Sideroxylon inerme (Sapotaceae), Euclea undulata (Ebenaceae) - also show foliage growth during summer, followed by leaf fall (Figure 4, after Specht et al. 1983). Elytropappus rhinocerotis (Asteraceae) - an understorey survivor of the Olea-Sideroxylon overstorey of the Renosterveld - develops new foliage shoots during the wettest season of the year (Figure 4).

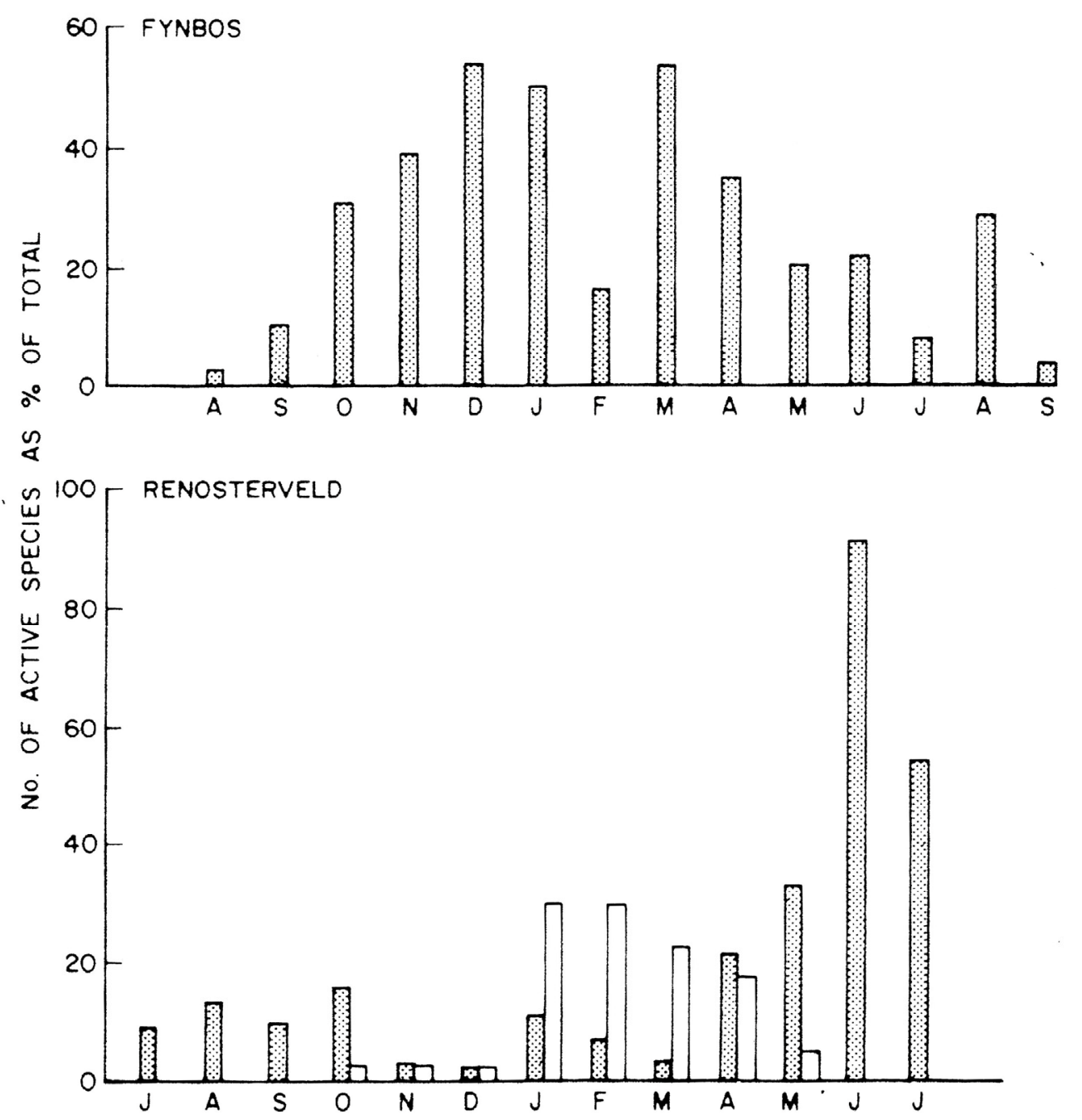

Figure 4. Seasonal shoot growth and leaf fall in Coastal Fynbos (heathland) on strongly leached soils and in remnant stands of Rhenosterveld on moderately leached soils in the Mediterranean-type climate region of South Africa (Specht et al. 1983)

Main study plants in Coastal Fynbos: Leucospermum parile (overstorey); Thamnochortus punctatus (understorey).

Main study plants in Rhenosterveld: Olea europaea subsp. africana and Sideroxylon inerme (in remnant 
overstorey); Elytropappus rhinocerotis (understorey).

Shaded bars: percentage of species growing; open bars: percentage of overstorey species losing leaves in Rhenosterveld.

A savanna understorey of $\mathrm{C} 3$ and $\mathrm{C} 4$ grasses dominates the vegetation on median-nutrient soils in humid and sub-humid climates throughout much of South Africa. In the Mediterranean-type climate of southern Africa, C3 grasses grow during spring into early summer, whereas $\mathrm{C} 4$ Themeda triandra has a growth rhythm in late spring through summer - surviving on soil moisture stored during the wet winter-spring seasons. C3 grass genera also grow in Afro-alpine habitats wherever temperatures are too low for $\mathrm{C} 4$ grasses (Figure $5)$.

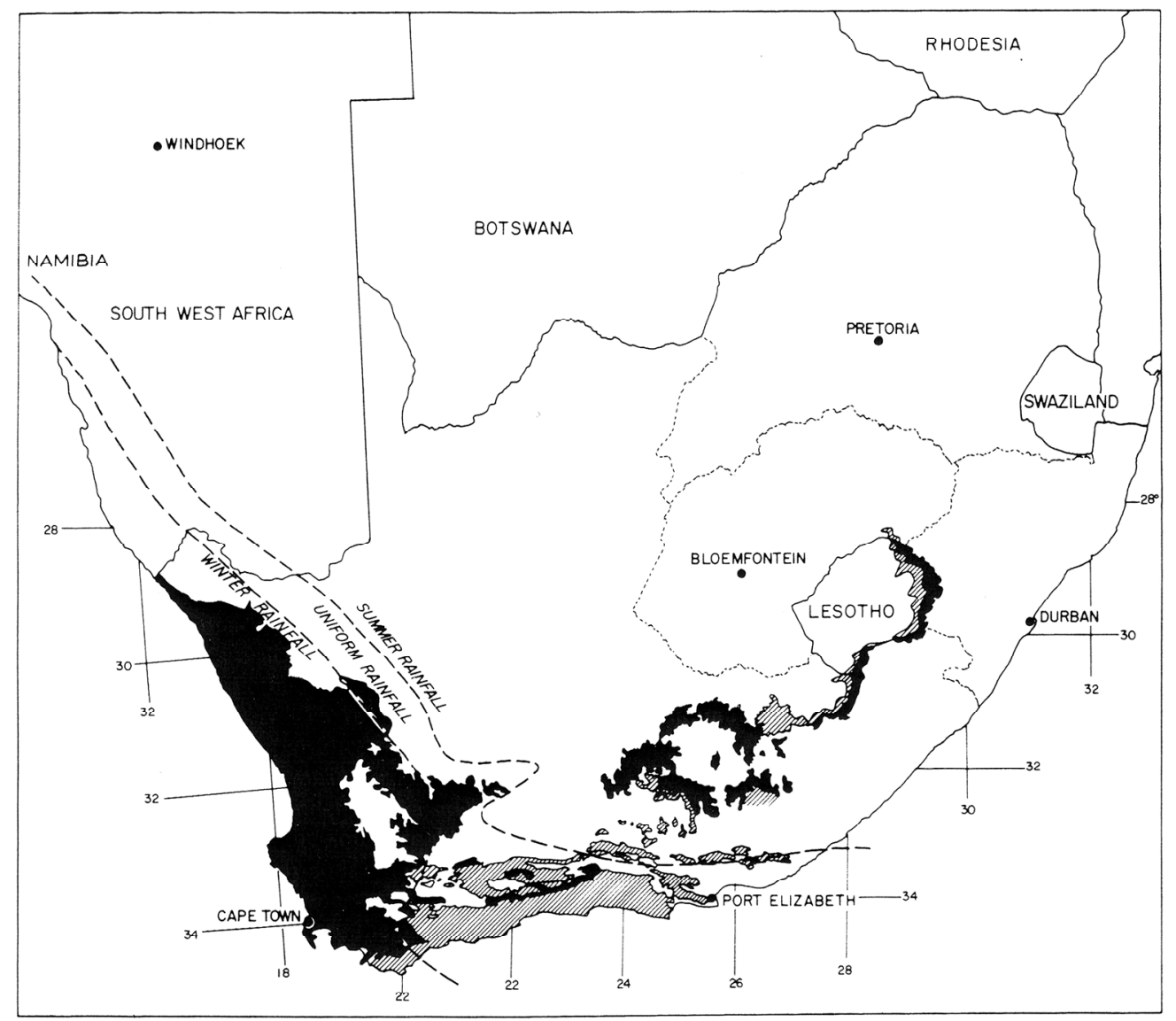

Figure 5. The distribution of $\mathrm{C} 3$ and $\mathrm{C} 4$ grasses in southern Africa and their relation to the three rainfall zones (Werger 1986, Figure 8.27, after Vogel et al. 1978)

Unshaded area has more than $90 \%$ of the grass cover of the C4 type; black area has more than $90 \%$ of the grass cover of the $\mathrm{C} 3$ type; hatched area has intermediate amounts of cover of $\mathrm{C} 3$ and $\mathrm{C} 4$ grasses.

Foliage Projective Cover: The Foliage Projective Covers (FPCs) of overstorey and understorey strata in South African plant communities appear to be similar to those recorded in Australia - correlated with the community-physiological constant, the Evaporative Coefficient (k) of the meteorological site (Figure 6). Plant communities in the arid climatic 
zone $\left(\mathrm{k}<0.35 \times 10^{-2}\right)$ have an overstorey FPC of about $30 \%$ with an understorey FPC less than $30 \%$ - total FPC less than $60 \%$. As the climate improves from the arid through the semi-arid and the subhumid climatic zones to the humid climatic zone $(\mathrm{k}=$ between 0.55 and $0.75 \times 10^{-2}$ ), both overstorey FPCs and understorey FPCs increase to about $60 \%$ - total FPC over $120 \%$.

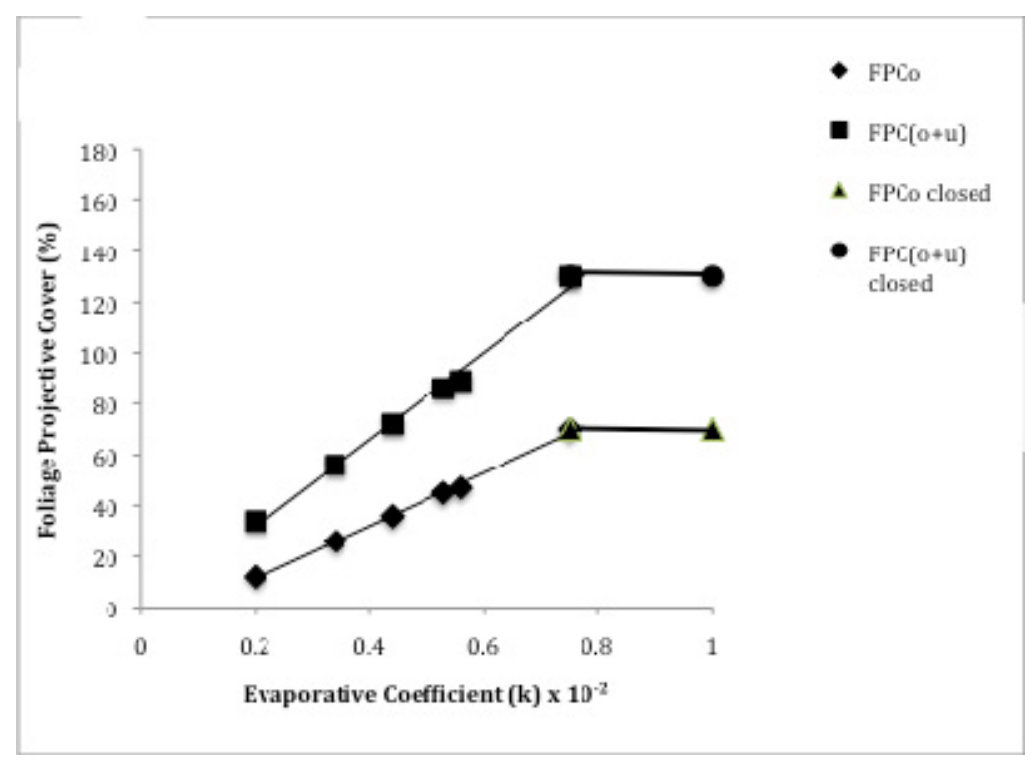

Figure 6. Foliage Projective Covers (FPCs) of the overstorey (o) stratum and the sum of FPCs recorded in both overstorey $(\mathrm{o})$ and understorey $(\mathrm{u})$ strata, $\mathrm{FPC}(\mathrm{o}+\mathrm{u})$, in South African plant communities in relation to the Evaporative Coefficient (k). FPC reaches a maximum in plant communities that have optimal soil water during the season of foliage growth - FPCo closed and $\mathrm{FPC}(\mathrm{o}+\mathrm{u})$ closed

$$
\begin{array}{ll}
\text { FPC (overstorey) }=104.1 \mathrm{k}-9.6 & \mathrm{r}^{2}=0.99 \\
\text { FPC (over + understorey) }=171.2 \mathrm{k}-2.6 & \mathrm{r}^{2}=0.99
\end{array}
$$

Range of Evaporative Coefficients $(\mathrm{k})$ in climatic zones - Arid Zone $\left(\mathrm{k}<0.35 \times 10^{-2}\right)$, Semi-arid Zone $(\mathrm{k}$ $\left.=0.35-0.45 \times 10^{-2}\right)$, Subhumid Zone $\left(\mathrm{k}=0.45-0.55 \times 10^{-2}\right)$, Humid Zone $\left(\mathrm{k}=0.55-0.75 \times 10^{-2}\right)$, Perhumid Zone $\left(\mathrm{k}>0.75 \times 10^{-2}\right)$.

In perhumid climates (with the Evaporative Coefficient over $0.75 \times 10^{-2}$ ) and in well-watered habitats within drier climates where available soil water is optimal during the season of foliage shoot growth, a closed-forest or closed-scrub, with Foliage Projective Covers markedly different from the adjacent open-structured plant communities, develops on median-nutrient soils (Figure 6). On nutrient-poor soils, a closed-heathland ( \pm tall Proteaceae) develops.

After fire in fynbos (heathland) vegetation in the south-west Cape, the Total FPC is reduced to zero. As the proteoid component of the fynbos rapidly regenerates, the understorey restioid understorey declines - with Total FPC reaching a plateau of 50-60\% in equilibrium with the Evaporative Coefficient of the area (Figure $7 \mathrm{a}$ and $7 \mathrm{~b}$ ). 
Bainskloof fynbos (0-40 yrs)

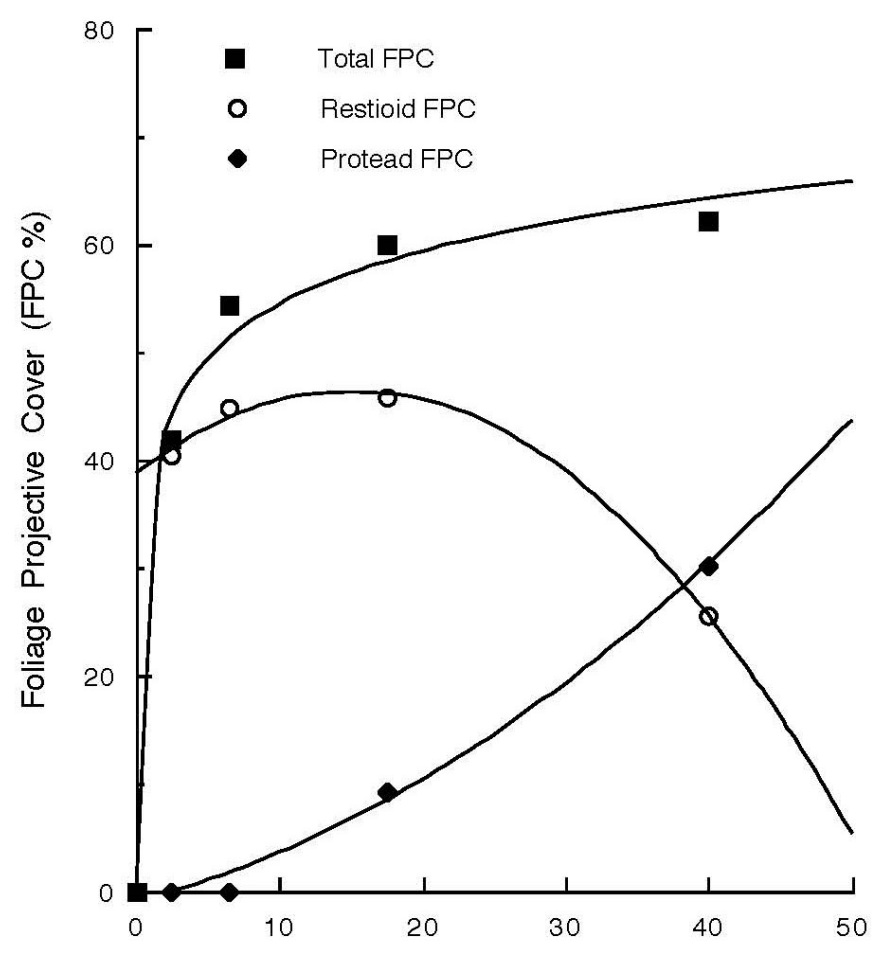

Age since fire in years

Figure 7a. Foliage Projective Covers (FPC) of Proteoid and Restioid components in four stands of fynbos - aged 2, 6, 18 and 40 years post-fire - at Bainskloof $\left(33^{\circ} 36^{\prime} \mathrm{S}, 19^{\circ}\right.$ 06'E).

Total $\mathrm{FPC}=16.46 \log ($ year $)+38.01$ 


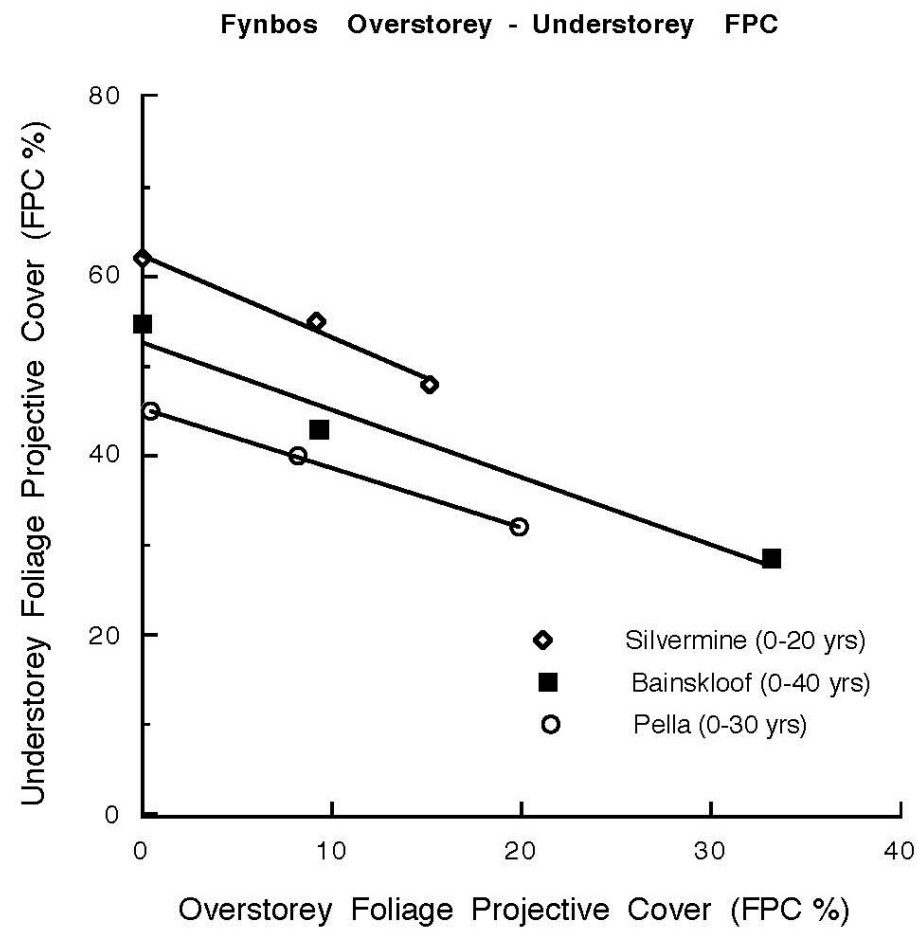

Figure 7b. The relationship of understorey Foliage Projective Cover (FPCo) to overstorey

Foliage Projective Cover ( $\mathrm{FPCu}$ ) during post-fire successions in fynbos vegetation at Silvermine $\left(34^{\circ} 05^{\prime} \mathrm{S}, 18^{\circ} 25^{\prime} \mathrm{E}\right)$, Bainskloof ( $\left.33^{\circ} 36^{\prime} \mathrm{S}, 19^{\circ} 06^{\prime} \mathrm{E}\right)$ and Pella $\left(33^{\circ} 31^{\prime} \mathrm{S}, 18^{\circ}\right.$ 32 'E)

$$
\begin{gathered}
\text { Silvermine }-\mathrm{FPCu}=-0.908 \mathrm{FPCo}+62.38 \\
\text { Bainskloof }-\mathrm{FPCu}=-0.751 \mathrm{FPCo}+52.66 \\
\text { Pella }-\mathrm{FPCu}=-0.671 \mathrm{FPCo}+45.40
\end{gathered}
$$

Alpha Biodiversity (species richness - number of species per unit area): Table 5 lists the species richness (number of species per $1000 \mathrm{~m}^{2}$ and per hectare) recorded in plant communities in the warm temperate Capensis Region of South Africa. As the fynbos (heathland) vegetation on the nutrient-poor quartzitic/sandstone ranges (Figure 8) was the focus of these studies (Bond 1983, 1988; Cowling 1988), only a few observations were made on the remnant vegetation on median-nutrient soils surviving at the fringes of these outcrops. Species richness (per hectare) of these lowland sites appears to increase linearly from about $30 \mathrm{spp}$. in the arid climatic zone $\left(\mathrm{k}<0.35 \times 10^{-2}\right)$ to about $80 \mathrm{spp}$. in the humid climatic zone $\left(\mathrm{k}=0.55-0.75 \times 10^{-2}\right)$ (Figure 9).

Table 5. Species richness (number of species per hectare) of plant communities in the Capensis Region of South Africa (Bond 1983, 1988; Cowling 1988).

\begin{tabular}{|l|c|c|c|}
\hline Plant community & $\begin{array}{c}\text { Species } \\
\text { richness } \\
\left(\text { per } 1000 \mathrm{~m}^{2}\right)\end{array}$ & $\begin{array}{c}\text { Species } \\
\text { richness } \\
(\text { per hectare })\end{array}$ & $\begin{array}{c}\text { Evaporative } \\
\text { Coefficient } \\
\left(\mathrm{k} \mathrm{x} \mathrm{10^{-2 }}\right) \\
. .\end{array}$ \\
\hline Swartberg Mts $\left(33^{\circ} 22^{\prime} \mathrm{S}, 21^{\circ} 55^{\prime} \mathrm{E}\right)$ - Bond 1988 & & & 0.35 \\
\hline
\end{tabular}




\begin{tabular}{|c|c|c|c|}
\hline $\begin{array}{l}\text { Tall open proteoid shrubland - } \\
\text { With heath understorey }\end{array}$ & 67 & 83 & \\
\hline $\begin{array}{l}\text { Tall open proteoid shrubland - } \\
\text { With restioid heath understorey }\end{array}$ & 46 & 61 & \\
\hline Low closed Erica heath & 90 & 118 & \\
\hline Low open heathland - arid fynbos & 59 & 73 & \\
\hline Arid fynbos - renosterveld transition & 49 & 62 & \\
\hline Renosterveld & 28 & 31 & \\
\hline Succulent karoo & 36 & 47 & \\
\hline $\begin{array}{l}\text { Baviaanskloof Mts }\left(33^{\circ} 30^{\prime} \mathrm{S}, 24^{\circ} 15^{\prime} \mathrm{E}\right)-\text { Bond } \\
1988\end{array}$ & & & 0.35 \\
\hline $\begin{array}{c}\text { Tall closed proteoid shrubland - } \\
\text { With heath understorey }\end{array}$ & 77 & 90 & \\
\hline $\begin{array}{l}\text { Tall open proteoid shrubland - } \\
\text { With heath understorey }\end{array}$ & 64 & 93 & \\
\hline $\begin{array}{l}\text { Tall proteoid shrubland - } \\
\text { With grassy heath understorey }\end{array}$ & 75 & 98 & \\
\hline Low grassy heathland & 65 & 80 & \\
\hline Karroid shrubland & 49 & 60 & \\
\hline Valley bushveld (Short, spinescent thicket) & 79 & 100 & \\
\hline Outeniqua Mts $\left(33^{\circ} 45^{\prime} \mathrm{S}, 21^{\circ} 50^{\prime} \mathrm{E}\right)-$ Bond 1988 & & & 0.45 \\
\hline Closed proteoid shrubland - heath understorey & 55 & 65 & \\
\hline Tall open proteoid shrubland - heath understorey & 65 & 75 & \\
\hline Low open heathland - arid fynbos & 60 & 80 & \\
\hline $\begin{array}{l}\text { Tall open shrubland (Protea nitida) - heath } \\
\text { understorey } \\
\text { (waboomveld) }\end{array}$ & 104 & 135 & \\
\hline Tsitsikama Mts $\left(33^{\circ} 50^{\prime} \mathrm{S}, 23^{\circ} 03^{\prime} \mathrm{E}\right)-$ Bond 1988 & & & 0.45 \\
\hline Tall open shrubland - heath understorey & 45 & 53 & \\
\hline Tall open shrubland - grassy heath understorey & 69 & 82 & \\
\hline \multicolumn{4}{|l|}{ George $\left(35^{\circ} 57^{\prime} \mathrm{S}, 22^{\circ} 28^{\prime} E\right)-$ Bond 1988} \\
\hline Moist forest & 52 & 66 & 0.57 \\
\hline $\begin{array}{r}\begin{array}{c}\text { Bontebok N.P., Swellendam } \\
\text { (Cowling 1988) }\end{array} \\
\left(34^{\circ} 10^{\prime} \mathrm{S}, 20^{\circ} 30^{\prime} \mathrm{E}\right) \\
\end{array}$ & & & 0.35 \\
\hline South Coast renosterveld & 60 & 72 & \\
\hline $\begin{array}{c}\text { Burtkraal (near Grahamstown) }\left(33^{\circ} 20^{\prime} \mathrm{S}, 26^{\circ} 30^{\prime} \mathrm{E}\right) \\
\text { (Cowling 1988) }\end{array}$ & & & 0.49 \\
\hline South Coast renosterveld & 95 & 115 & \\
\hline $\begin{array}{c}\text { Elandsberg Mts }\left(33^{\circ} 45^{\prime} \mathrm{S}, 25^{\circ} 00^{\prime} \mathrm{E}\right) \\
(\text { Cowling } 1988)\end{array}$ & & & 0.38 \\
\hline Mountain fynbos (proteoid - restioid) & 41 & 57 & \\
\hline $\begin{array}{l}\text { Knysna Afro-montane forest } \\
\text { (Rapanea - Canthium) }\end{array}$ & 53 & 71 & \\
\hline Gamtoos $\left(33^{\circ} 50^{\prime} \mathrm{S}, 25^{\circ} 00^{\prime} \mathrm{E}\right)-$ Cowling 1988 & & & 0.38 \\
\hline $\begin{array}{l}\text { Kaffarian succulent thicket } \\
\text { (Sideroxylon - Euphorbia) }\end{array}$ & 61 & 84 & \\
\hline $\begin{array}{l}\text { Kaffarian succulent thicket } \\
\qquad \text { (Euclea-Brachylaena) }\end{array}$ & 98 & 150 & \\
\hline Humansdorp (34 $\left.07^{\circ} \mathrm{S}, 24^{\circ} 47^{\prime} \mathrm{E}\right)-$ Cowling 1988 & & & 0.38 \\
\hline Grassy fynbos - Protea-Clutia & 87 & 125 & \\
\hline Grassy fynbos - Thamnochortus-Tristachya & 74 & 100 & \\
\hline Grassy fynbos - Thamnochortus-Erica & 45 & 55 & \\
\hline South Coast dune fynbos - Restio-Maytenus & 55 & 75 & \\
\hline South Coast dune fynbos - Restio-Agathosma & 60 & 88 & \\
\hline South Coast renosterveld - Eltyropappus, etc. & 93 & 140 & \\
\hline
\end{tabular}




\section{Macrothink}

Journal of Environment and Ecology

ISSN 2157-6092

2014, Vol. 5, No. 2

\begin{tabular}{|c|c|c|c|}
\hline Kaffarian thicket-Pterocelastrus-Gonioma & 71 & 103 & \\
\hline Kaffarian thicket-Cassine-Cussonia & 37 & 47 & \\
\hline $\begin{array}{c}\text { Cape Town (Signal Hill) }\left(33^{\circ} 57^{\prime} \mathrm{S}, 18^{\circ} 30^{\prime} \mathrm{E}\right) \\
\text { (Cowling 1988) }\end{array}$ & & & 0.32 \\
\hline West Coast Strandveld & 99 & 118 & \\
\hline Koeberg $\left(33^{\circ} 46^{\prime} \mathrm{S}, 18^{\circ} 28^{\prime} \mathrm{E}\right)-$ Cowling 1988 & & & 0.35 \\
\hline West Coast Strandveld-Putterlickia-Rhus & 35 & 46 & \\
\hline Tygerberg (33 $\left.{ }^{\circ} 50^{\prime} \mathrm{S}, 18^{\circ} 30^{\prime} \mathrm{E}\right)$ - Cowling 1988 & & & 0.35 \\
\hline West Coast Strandveld -Elytropappus-Aristida & 103 & 135 & \\
\hline
\end{tabular}

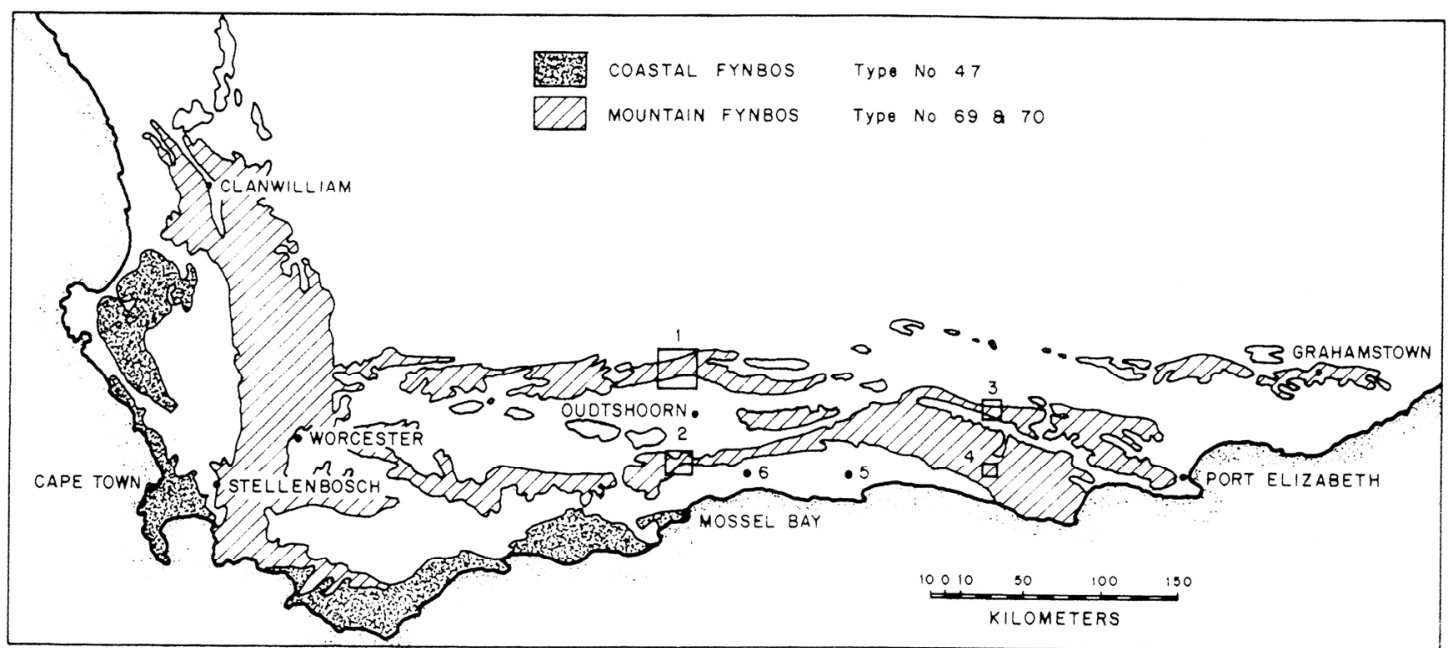

Figure 8. The study areas in the fynbos (heathland) biome in the southern Cape Province of South Africa (Bond 1983)

1. Swartberg; 2. Outeniquas; 3. Baviaanskloof; 4. Tsitsikamma; 5. Fynbos 'island' (Dirk se Eiland); 6. Moist forest. 


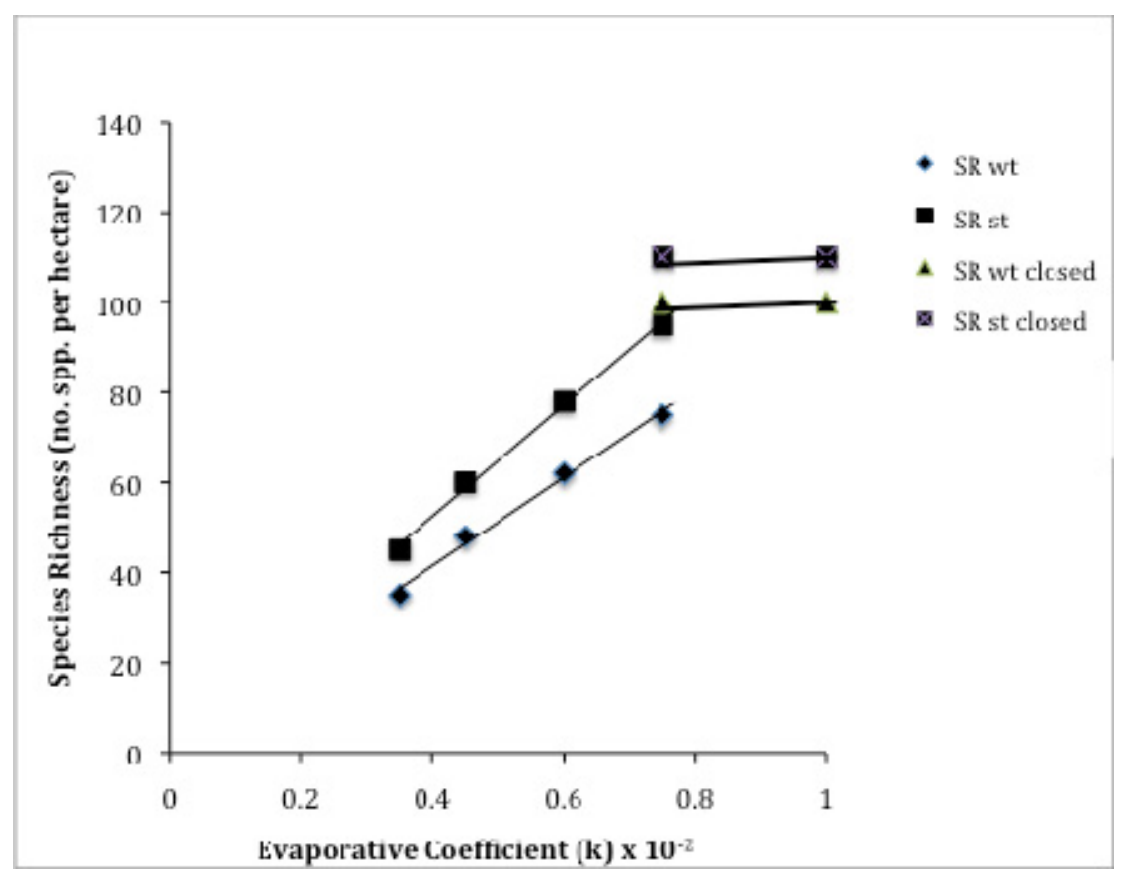

Figure 9. Species richness (SR, number of vascular plant species per hectare) of plant communities in the warm temperate (SR wt) and subtropical (SR st) regions of South Africa in relation to the Evaporative Coefficient $(\mathrm{k})$. A sharp increase in species richness is found in plant communities that have optimal soil water during the season of foliage growth $-\mathrm{SR} w \mathrm{t}$ closed and SR st closed

$$
\begin{array}{ll}
\text { SR }(\text { Warm Temp. })=95.2 \mathrm{k}+6.1 & \mathrm{r}^{2}=0.95 \\
\text { SR }(\text { Subtropical })=125.6 \mathrm{k}+2.2 & \mathrm{r}^{2}=0.99
\end{array}
$$

Range of Evaporative Coefficients $(\mathrm{k})$ in climatic zones - Arid Zone $(\mathrm{k}<0.35 \mathrm{x}$ 10-2), Semi-arid Zone ( $\mathrm{k}=0.35-0.45 \times 10-2)$, Subhumid Zone $(\mathrm{k}=0.45-0.55 \times 10-2)$, Humid Zone $(\mathrm{k}=0.55-0.75 \times 10-2)$, Perhumid Zone $(\mathrm{k}>0.75 \times 10-2)$.

The species richness (per hectare) of vegetation on median-nutrient soils in the subtropical climate, north of the warm temperate Capensis Region of South Africa, was estimated by the total number of species that had been recorded on random relevé 'survey plots' (only 25-50 $\mathrm{m}^{2}$ in area) in the Karoo-Namib Region (Table 6) and in the Austral Domain of the Sudano-Zambesian Region (Table 7) — values confirmed in recent species richness studies in stations along the BIOTA transects in southern Africa (Table 8). The higher ambient temperatures experienced during the short shoot-growth rhythm in this subtropical climate will produce more leaves per vertical foliage shoot, thus higher net photosynthesis per annum and higher species richness (Figure 9). 
Table 6. Species richness (number of species per 'plot' of $25-50 \mathrm{~m}^{2}$ ) of plant communities in the Karoo - Namib Region of South Africa (Werger 1978b) and Welwitschia Plain, Namibia (Moisel \& Moll 1981)

\begin{tabular}{|c|c|c|c|}
\hline Plant community & $\begin{array}{c}\text { Species richness } \\
(\mathrm{spp} . \text { per } \\
\left.25-50 \mathrm{~m}^{2}\right)\end{array}$ & $\begin{array}{l}\text { Species richness } \\
\text { (spp. per hectare) }\end{array}$ & $\begin{array}{c}\text { Evaporative } \\
\text { Coefficient } \\
\left(\mathrm{k} \times 10^{-2}\right)\end{array}$ \\
\hline \multicolumn{4}{|l|}{ Central Namib (Robinson 1977) } \\
\hline Acacia erioloba community - in washes & 3 & 10 & \\
\hline Faidherbia albida community - in rivers & 2 & 8 & \\
\hline \multicolumn{4}{|l|}{$\begin{array}{l}\text { Augrabies Falls N.P. (Werger \& Coetzee } \\
\text { 1977) }\end{array}$} \\
\hline Schotia afra community - on river sides & 14 & 30 & \\
\hline \multicolumn{4}{|l|}{ Southern Kalahari (Leistner \& Werger 1973) } \\
\hline Stipagrostis amabilis + Acacia spp. & 10 & 22 & 0.20 \\
\hline \multicolumn{4}{|l|}{$\begin{array}{l}\text { Northern Cape Province } \\
\quad \text { (Dept Agricultural Technical Services) }\end{array}$} \\
\hline $\begin{array}{c}\text { Western Mtn Karoo - Elytropappus } \\
\text { rhinocerotis }\end{array}$ & 25 & 55 & 0.35 \\
\hline Succulent Karoo - Stipagrostis zeyheri & 20 & 45 & 0.35 \\
\hline $\begin{array}{c}\text { Succulent Karoo - Chaetobromus } \\
\text { dregeanus }\end{array}$ & 32 & 75 & \\
\hline $\begin{array}{l}\text { Succulent Karoo } \\
\text { Tetragonia-Stipagrostis }\end{array}$ & 5 & 12 & 0.10 \\
\hline $\begin{array}{c}\text { Bushmanland - Stipagrostis brevifolia - } \\
\text { sand flat }\end{array}$ & 2 & 8 & \\
\hline \multicolumn{4}{|l|}{ Karoo Domain (Werger 1973) } \\
\hline Zizipho - Rhigozetum obovati & 20 & 45 & \\
\hline $\begin{array}{c}\text { Melhania rehmannii - Hermannietum } \\
\text { spinosae }\end{array}$ & 9 & 20 & 0.22 \\
\hline Monoechmatetum incani & 12 & 28 & 0.22 \\
\hline Nestlero humilis - Pteronietum sordidae & 10 & 22 & 0.22 \\
\hline Eriocephalo - Eberlanzietum & 15 & 33 & 0.22 \\
\hline \multicolumn{4}{|l|}{$\begin{array}{l}\text { Namibia (Moisel \& Moll 1981) } \\
\qquad\left(22^{\circ} 45^{\prime} \mathrm{S}, 15^{\circ} 01^{\prime} \mathrm{E}\right)\end{array}$} \\
\hline Community 1 on marble $\&$ dolerite soils & 9 per $500 \mathrm{~m}^{2}$ & 15 & 0.10 \\
\hline Community 2 on granite $\&$ gravel soils & 10 per $800 \mathrm{~m}^{2}$ & 16 & 0.10 \\
\hline Community 3 on fine sand & 8 per $600 \mathrm{~m}^{2}$ & 14 & 0.10 \\
\hline
\end{tabular}


Table 7. Species richness (number of species per 'plot' of $25-50 \mathrm{~m}^{2}$ ) of plant communities in the Austral Domain of the Sudano-Zambezian Region of South Africa (Werger \& Coetzee 1978)

\begin{tabular}{|c|c|c|c|}
\hline Plant community & $\begin{array}{l}\text { Species richness } \\
\text { (spp. per } \\
\left.25-50 \mathrm{~m}^{2}\right)\end{array}$ & $\begin{array}{l}\text { Species richness } \\
\text { (spp. per } \\
\text { hectare) }\end{array}$ & $\begin{array}{l}\text { Evaporative Coefficient } \\
\left(\mathrm{k} \mathrm{x} 10^{-2}\right)\end{array}$ \\
\hline \multicolumn{4}{|l|}{$\begin{array}{l}\text { Broad-orthophyll Plains Bushveld (Myre } \\
\text { 1971) }\end{array}$} \\
\hline $\begin{array}{c}\text { Andropogono gayani - Corchoretum } \\
\text { junodii }\end{array}$ & $(6+21)^{*}=27$ & 60 & 0.45 \\
\hline \multicolumn{4}{|l|}{$\begin{array}{c}\text { Microphyllous Thorny Plains Bushveld } \\
\text { (Myre1971) }\end{array}$} \\
\hline $\begin{array}{l}\text { Themedo - Turbinetum oblongatae } \\
\text { (subassoc. typicum on dark clayey soils) }\end{array}$ & $(3+11)=14$ & 38 & \\
\hline $\begin{array}{l}\text { Themedo - Turbinetum oblongatae } \\
\text { (subassoc. albizietosum, on more sandy } \\
\text { soils) }\end{array}$ & $(6+20)=26$ & 60 & 0.45 \\
\hline
\end{tabular}

* Total number of species recorded $=$ (overstorey species + understorey species $)$

Table 8. Species richness (number of species per $100 \mathrm{~m}^{2}, 1000 \mathrm{~m}^{2}$ and 1 hectare) of vascular plants along the BIOTA transects in southern Africa (Schmeidel et al. 2010).

\begin{tabular}{|c|c|c|c|c|}
\hline \multirow{2}{*}{ Plant community } & \multicolumn{3}{|c|}{ Species richness } & \multirow{2}{*}{$\begin{array}{c}\text { See also Table } \\
\text { No. } \\
\end{array}$} \\
\hline & (spp. per $100 \mathrm{~m}^{2}$ ) & $\left(\right.$ spp. per $\left.1000 \mathrm{~m}^{2}\right)$ & (spp. per hectare) & \\
\hline \multicolumn{5}{|l|}{$\begin{array}{l}\text { Subtropical - } \\
\text { Subhumid Zone }\end{array}$} \\
\hline Woodland Savanna & 21 & 42 & 60 & Table 7 \\
\hline Thornbush Savanna & 28 & 48 & 63 & Table 7 \\
\hline \multicolumn{5}{|l|}{$\begin{array}{r}\text { Subtropical - } \\
\text { Arid Zone }\end{array}$} \\
\hline Nama Karoo & 12 & 20 & 35 & Table 6 \\
\hline Namib Desert & 2 & 3 & 4 & Table 6 \\
\hline \multicolumn{5}{|l|}{$\begin{array}{r}\text { Warm temperate - } \\
\text { Northern Cape }\end{array}$} \\
\hline Succulent Karoo & 29 & 57 & 80 & Table 6 \\
\hline \multicolumn{5}{|l|}{$\begin{array}{c}\text { Warm temperate - } \\
\text { Humid Zone }\end{array}$} \\
\hline Fynbos - closed & 53 & 91 & 121 & Table 5 \\
\hline
\end{tabular}

In habitats that are well supplied with soil water during the season of foliage shoot growth, Foliage Projective Cover (FPC) abruptly changes to maximum to produce a closed-structured community (Figure 6) - species richness values of the closed-communities increase greatly (Figure 9). Coastal rainforests develop in the well-watered, nutrient-rich sites along the 
subtropical, eastern coast (Moll \& White 1978) while Afro-montane rainforests occur in similar well-watered habitats in the Drakensberg Range (White 1978). However, the lower temperatures in the Drakensberg reduce vertical shoot growth compared with the temperatures experienced along the coast, thus reducing net photosynthesis per year and species richness of the rainforest stands - $(70 \pm 14)$ species-composition in Afro-montane Rainforests, compared with $(131 \pm 11)$ species-composition in Coastal Rainforests (Table 9). As solar radiation is less in the warm temperate Capensis Region (latitude 33-35 $\mathrm{S}$ ) than in the subtropical Indian Ocean Coastal Belt (latitude 25-32 ${ }^{\circ}$ S) (Specht et al. 1992), annual foliage shoot growth is reduced (Specht, A. \& Specht 1993, 1994), thus resulting in less annual net photosynthesis and species richness - $71 \mathrm{spp}$. in the Knysna rainforest, decreasing to $47 \mathrm{spp}$. in the rainforest stand near Kirstenbosch (Table 9).

Table 9. Species richness (number of species recorded) in closed-forests (over 100 hectares in area) in the Indian Ocean Coastal Belt (Cooper \& Swart 1992), the Dwesa Forest Reserve (Moll 1974) and the Capensis Region (Bond 1983, 1988; Campbell \& Moll 1977; McKenzie et al. 1990)

\begin{tabular}{|c|c|}
\hline Closed-forest community & Species richness \\
\hline \multicolumn{2}{|l|}{$\begin{array}{c}\text { Indian Ocean Coastal Belt } \\
\text { Afromontane rainforests } \\
\text { (Cooper \& Swart 1992) }\end{array}$} \\
\hline $31^{\circ} 01^{\prime} \mathrm{S} 29^{\circ} 20^{\prime} \mathrm{E}$ & $\sim 95$ spp. \\
\hline $31^{\circ} 28^{\prime} \mathrm{S} 28^{\circ} 36^{\prime} \mathrm{E}$ & $\sim 75$ spp. \\
\hline $31^{\circ} 26^{\prime} \mathrm{S} 28^{\circ} 46^{\prime} \mathrm{E}$ & $\sim 70$ spp. \\
\hline $30^{\circ} 09^{\prime} \mathrm{S} 29^{\circ} 47^{\prime} \mathrm{E}$ & $\sim 80 \mathrm{spp}$ \\
\hline $30^{\circ} 22^{\prime} \mathrm{S} 29^{\circ} 26^{\prime} \mathrm{E}$ & $\sim 60 \mathrm{spp}$. \\
\hline $30^{\circ} 51^{\prime} \mathrm{S} 29^{\circ} 26^{\prime} \mathrm{E}$ & $\sim 50 \mathrm{spp}$ \\
\hline $30^{\circ} 03^{\prime} \mathrm{S} 29^{\circ} 30^{\prime} \mathrm{E}$ & $\sim 60$ spp. \\
\hline \multicolumn{2}{|l|}{$\begin{array}{l}\text { Indian Ocean Coastal Belt } \\
\text { Coastal rainforests } \\
\text { (Cooper \& Swart 1992) }\end{array}$} \\
\hline $31^{\circ} 49^{\prime} \mathrm{S} 29^{\circ} 17^{\prime} \mathrm{E}$ & $\sim 123$ spp. \\
\hline $31^{\circ} 32^{\prime} \mathrm{S} 29^{\circ} 39^{\prime} \mathrm{E}$ & $\sim 140 \mathrm{spp}$. \\
\hline $31^{\circ} 32^{\prime} \mathrm{S} 29^{\circ} 39^{\prime} \mathrm{E}$ & $\sim 130 \mathrm{spp}$. \\
\hline $32^{\circ} 27^{\prime} \mathrm{S} 28^{\circ} 36^{\prime} \mathrm{E}$ & $\sim 150 \mathrm{spp}$. \\
\hline $32^{\circ} 37^{\prime} \mathrm{S} 29^{\circ} 23^{\prime} \mathrm{E}$ & $\sim 130 \mathrm{spp}$. \\
\hline $31^{\circ} 37^{\prime} \mathrm{S} 29^{\circ} 34^{\prime} \mathrm{E}$ & $\sim 130 \mathrm{spp}$. \\
\hline $31^{\circ} 35^{\prime} \mathrm{S} 29^{\circ} 34^{\prime} \mathrm{E}$ & $\sim 110$ spp. \\
\hline $31^{\circ} 27^{\prime} \mathrm{S} 29^{\circ} 42^{\prime} \mathrm{E}$ & $\sim 125$ spp. \\
\hline $31^{\circ} 27^{\prime} \mathrm{S} 29^{\circ} 45^{\prime} \mathrm{E}$ & $\sim 125$ spp. \\
\hline $31^{\circ} 30^{\prime} \mathrm{S} 29^{\circ} 41^{\prime} \mathrm{E}$ & $\sim 130$ spp. \\
\hline \multicolumn{2}{|l|}{$\begin{array}{c}\text { Dwessa Forest Reserve, } \\
\text { Transkei (Moll 1974) }\end{array}$} \\
\hline $32^{\circ} 10^{\prime} \mathrm{S} 28^{\circ} 57^{\prime} \mathrm{E}$ & $\sim 150$ spp. \\
\hline \multicolumn{2}{|l|}{$\begin{array}{l}\text { Capensis Region } \\
\text { Afromontane rainforests }\end{array}$} \\
\hline $\begin{array}{c}\text { George }\left(35^{\circ} 57^{\prime} \mathrm{S} 22^{\circ} 28^{\prime} \mathrm{E}\right) \\
\text { (Bond } 1983,1988)\end{array}$ & $\sim 66$ spp. per hectare \\
\hline
\end{tabular}




\begin{tabular}{|c|c|}
\hline $\begin{array}{c}\left.\text { Knysna (33 }{ }^{\circ} 45^{\prime} \mathrm{S} 25^{\circ} 00^{\prime} \mathrm{E}\right) \\
(\text { Cowling } 1988)\end{array}$ & $\sim 71 \mathrm{spp}$. per hectare \\
\hline $\begin{array}{c}\text { Kirstenbosch } \\
\left(33^{\circ} 59^{\prime} \mathrm{S} 18^{\circ} 26^{\prime} \mathrm{E}\right) \\
(\text { Campbell \& Moll 1977) }\end{array}$ & $\sim 47 \mathrm{spp}$. per hectare \\
\hline $\begin{array}{c}\text { Capensis Region } \\
\text { Coastal rainforests }\end{array}$ & $\sim 32$ spp. per hectare \\
\hline $\begin{array}{c}\text { Platbos, near Hermanus } \\
\left(34^{\circ} 25^{\prime} \mathrm{S} 19^{\circ} 15^{\prime} \mathrm{E}\right) \\
(\text { McKenzie } \text { et al. } 1990)\end{array}$ & \\
\hline
\end{tabular}

Species richness (per hectare) in well-watered sites in the nutrient-poor fynbos stands and proteoid thickets on the infertile quartzitic/sandstone ranges in the Capensis Region (Table 5) also show much higher values (90-135 spp.) than in fynbos on habitats droughted during the season of foliage growth (circa $60 \mathrm{spp}$.).

Cyclic salt in sea-winds: Wind speeds that are produced by the Roaring Forties are exceedingly high across the southern shores of South Africa (Table 10). Even in southern Australia, these strong winds blow inland high levels of sodium chloride in the atmosphere (Isbell et al. 1983) that appear to limit the growth of the C4 grasses such as Themeda triandra - that needs minute traces of sodium for the $\mathrm{C} 4$ dicarboxylic photosynthetic pathway (Brownell \& Crossland 1972). The input of cyclic salt in the strong winds of south-western Cape Province appear to have inhibited the growth of $\mathrm{C} 4$ grasses, except in sheltered pockets on nutrient-rich soils (Figure 5); further east across Cape Province where the winds are slower, an admixture of $\mathrm{C} 3$ and $\mathrm{C} 4$ grasses survive (Figure 5). As in Australia, the $\mathrm{C} 4$ grass, Themeda triandra, is widespread in subtropical South Africa, where cyclic salt is low; it even forms a 'lawn-type' savanna on the coast south of Port St Johns — similar to such communities on headlands in eastern Australia.

Table 10. Mean wind speed ( $\mathrm{km} \mathrm{hr}-1)$ and pan evaporation ( $\mathrm{mm}$ per annum) data recorded at climate stations within the Mediterranean-type climatic regions of South Africa and Australia (Specht \& Moll 1983; Specht \& Specht 1999).

\begin{tabular}{|l|c|c|c|c|}
\hline \multirow{2}{*}{ Climate station } & \multicolumn{3}{|c|}{ Mean wind speed $\left(\mathrm{km} \mathrm{hr}^{-1}\right)$} & \multirow{2}{*}{$\begin{array}{c}\text { Pan evaporation } \\
\text { (mm per annum) }\end{array}$} \\
\cline { 2 - 4 } & January & July & Year & \\
\hline $\begin{array}{c}\text { Cape Town, } \\
\text { South Africa }\end{array}$ & 22.4 & 15.4 & 17.4 & 2049 \\
\hline $\begin{array}{c}\text { Port Elizabeth, } \\
\text { South Africa }\end{array}$ & 19.5 & 13.8 & 17.1 & 1920 \\
\hline $\begin{array}{c}\text { Perth, } \\
\text { Western Australia }\end{array}$ & 17.5 & 14.2 & 15.8 & 1480 \\
\hline $\begin{array}{c}\text { Adelaide, } \\
\text { South Australia }\end{array}$ & 12.6 & 11.6 & 12.2 & 1206 \\
\hline $\begin{array}{c}\text { Melbourne, } \\
\text { Victoria }\end{array}$ & 13.5 & 13.0 & 12.7 & 1205 \\
\hline
\end{tabular}




\section{Discussion}

The subtropical phenology - with foliage shoot growth between $15-25^{\circ} \mathrm{C}$ with a peak at $20^{\circ} \mathrm{C}$ - of plants in the heathlands ( \pm trees/tall shrubs) persists today in the warm temperate, Mediterranean-type climate of each continent (Specht \& Rayson 1957; Specht et al. 1981, 1983, 1992; Kruger 1981). Foliage growth in overstorey trees and tall shrubs — with internodes well ventilated between leaves - occurs during late spring through summer, when soil water is minimal. Foliage leaves in dicotyledonous understorey plants, on the other hand, are more closely packed than in the overstorey and trap solar energy momentarily so that foliage growth occurs earlier in spring (Specht \& Yates 1990, Specht et al. 1991a). Even greater amounts of solar energy are trapped in dense clumps of Cyperaceae or Restionaceae, thus enabling new shoots to be formed even during winter (Specht et al. 1983, 1991a).

The late spring through summer phenology is also found in the overstorey trees (Olea europaea spp. africana, Sideroxylon inerme, Euclea undulata, etc.) that formerly dominated the Renosterveld on median-nutrient soils of the Cape (Boucher \& Moll 1981). The Asteraceae (Elytropappus rhinocerotis, etc.) that now survive on remnant areas possess densely packed leaves that trap solar energy to enable foliage growth during the wetter seasons of the Mediterranean-type climate (Figure 4, after Specht et al. 1983).

The foliage growth rhythm of the overstorey during the dry Mediterranean climate appears to be assisted by the conservation of orthophosphates - released from litter-decomposition during the wet winter-spring — in polyphosphate granules in rootlets and associated rhizosphere organisms; this polyphosphate is hydrolysed back to orthophosphate when shoot growth begins in late spring-summer (Specht \& Groves 1966; Jeffrey 1964, 1967, 1968; Ashford et al. 1975; Coleman \& Specht 1981; Specht et al. 1983).

The C4-photosynthetic (Hatch \& Slack 1966) Gondwanan grass, Themeda triandra, that flourishes on nutrient-rich soils in south-eastern Australia wherever the input of sodium chloride in sea-spray is low (Isbell et al. 1983), also retain a subtropical growth rhythm in these Mediterranean-type climates - producing new foliage during late spring through summer when available soil moisture is lowest (Groves 1965; Stuwe \& Parsons 1977; Specht et al. 1983). Exotic C3 plants with a warm temperate growth rhythm are thus able to invade the median-nutrient savannas where soil moisture is highest during spring (Davies \& Sim 1931; Davies et al. 1934; Tiver \& Crocker 1951; Specht \& Clifford 1991; Moore 1993; Specht 2000). Even the heathy communities on nutrient-poor soils may be invaded by warm temperate exotic C3 species when the soil is enriched by ash after fire (Specht et al. 1958) especially if phosphate-pollution has occurred (Specht 1963; Heddle \& Specht 1975; Ozanne \& Specht 1981).

Subtropical grasslands ( \pm trees) - composed of many C4-photosynthetic Gondwanan genera that are common in South Africa and Australia (Table 2) - retain their seasonal growth rhythm between $15-25^{\circ} \mathrm{C}$ with a peak at $20^{\circ} \mathrm{C}$, often growing during the driest months of the year (Specht et al. 1991b; Specht \& Specht 1999). The photosynthetic pathway of all these C4 grasses need minute traces of sodium, blown far inland in sea-spray from the eastern 
coastlines (Brownell \& Crossland 1972) - possibly recycled in the saliva of grazing animals (McNaughton 1985).

The leaves of C4-grasses survive quite long periods of drought - even though appearing dry. As the water potential of the soil is slowly reduced, both water potential and net photosynthesis of the leaves decrease (Doley \& Trivett 1974). The organelles in these desiccation-tolerant leaves are rapidly restored to normal on the application of water (Mittelheuser 1977).

During the short period of foliage shoot growth, aerodynamic fluxes (frictional, thermal, evaporative) in the atmosphere as it flows over and through the plant community (Marshall 1971) influence the lateral growth of each plant within the plant community - determining the Foliage Projective Covers (FPCs) of the overstorey (o) and understorey (u) strata (Specht \& Morgan 1981; Specht 1983; Specht \& Specht 1999). The sum, $\Sigma($ FPCo + FPCu $)$, is a constant in space and time at each meteorological station.

At the same time as the Foliage Projective Covers of overstorey and understorey strata are determined in the plant community, the foliage attributes (Leaf Area, Leaf Specific Weight) of each newly-formed leaf, with their physiological-biochemical attributes, are determined Foliar N:P Ratio (Specht \& Rundel 1990; Specht \& Specht 2010; Stock \& Verboom 2012); stomatal resistance (Carbon Isotope Ratio, Farquhar \& Sharkey 1982; Farquhar \& Richards 1984; Schultze et al. 1998); Chlorophyll a/b Ratio (Gracia in Stewart et al. 1990); Nitrate Reductase Activity (Stewart et al. 1990).

The Foliage Projective Covers and leaf attributes in the overstorey and understorey strata determine the monthly evapotranspiration (per hectare) from the plant community. The monthly ratio of actual to potential evapotranspiration $(\mathrm{Ea} / \mathrm{Ep})$ per $\mathrm{mm}$ available soil water is a community-physiological constant - termed the Evaporative Coefficient $(\mathrm{k})$ - in plant communities in the Arid to the Humid Climatic Zones that experience seasonal drought. In sites where available soil water is optimal during the season of foliage growth, the $\Sigma$ (FPCo + $\mathrm{FPCu}$ ) asymptotes to maximum - a closed rainforest or closed scrub is formed on median-nutrient soils, a closed heathland ( \pm taller Proteaceae species) is formed on nutrient-poor soils (Figure 9). As available soil water under these closed plant communities fluctuates throughout the year, the net photosynthesis (and other physiological-biochemical processes, including monthly evapo-transpiration per hectare) of the Foliage Projective Cover (overstorey + understorey) of the vegetation varies accordingly (Doley et al. 1987; Mitchell et al. 2008; Lambers et al. 2012).

The amount of both available soil water and soil nutrients during this short period of foliage growth influences vertical foliage growth - the number of leaves and internode length but not their foliage attributes (Leaf Area, Leaf Specific Weight) or $\Sigma$ (FPCo + FPCu). Ambient temperature experienced during the short period of foliage growth also influence vertical foliage growth in the overstorey — in the gradient from temperate to tropical climates (Specht et al. 1992; Specht \& Specht 1999). Foliage attributes within the plant community are also influenced by the gradient in ambient temperature around developing foliage shoots in the strata from overstorey to ground layer (Specht \& Yates 1990; Specht et 
al. 1991a).

The combination of Foliage Projective Covers and number of leaves - and their foliage attributes - produced on vertical foliage shoots determine the Leaf Area Index (area of all leaves per hectare) in the plant community. The potential of the plant community to fix solar energy as net photosynthate each year is correlated with the Alpha Biodiversity (number of species per hectare) of plants in each plant community (Specht \& Specht 1989a, 1989b, 1989c; Specht, A. \& Specht 1993, 1994, 2001, 2011). The species richness of resident consumers (small mammals, birds, snakes, lizards and amphibia) — that depend on the energy fixed by the producers - is also correlated (Braithwaite et al. 1985; Specht, A. 1988; Specht 1994, 2012; Specht \& Specht 1999; Specht \& Tyler 2010).

Species richness of disjunct stands of closed-forests: As the growth of foliage at the edges of isolated stands of closed-rainforest is abraded by prevailing winds, the species-area-curve of these stands reaches a maximum at about 100 hectares (Specht, A. 1988; Specht 2007) - far larger than the species-area-curves of open-structured plant communities that asymptote at about a hectare in area or less (Specht et al. 1990; Specht \& Specht 1999; Specht 2012; Specht \& Tyler 2010). As annual solar radiation decreases with latitude, the species richness of closed-forests (rainforests) decreases as net photosynthesis per annum decreases in both eastern Australia and eastern South Africa.

Species richness of closed-heathlands and proteoid thickets (kwongan): On nutrient-poor lateritic soils in southwest Western Australia, a closed-heathland (with species richness 107.7 \pm 12.1 spp. per hectare, $\mathrm{n}=11$ ) may develop on lateritic soils (Havel 1975) or a tall sclerophyllous shrubland, termed kwongan (with species richness $109.3 \pm 13.9$ spp. per hectare, $\mathrm{n}=8$ ) may develop on the northern Swan Coastal Plain (Heddle 1980) — with much higher species richness than in open-heathlands $(59.8 \pm 4.5 \mathrm{spp}$. per hectare, $\mathrm{n}=9)$ on sites experiencing seasonal drought (George et al. 1979, 1988; Bell \& Watson 1988). Similarly, closed-heathlands and proteoid thickets, with species richness of 90-135 species per hectare develop in well-watered sites on the infertile quartzite/sandstone ranges in the Capensis Region - much greater than in adjacent stands of open-heathland with species richness about 60 species per hectare.

\section{Conclusions}

The community-physiological processes that determine the structure, growth and biodiversity in Australian plant communities also apply to the Gondwanan vegetation of South Africa heathlands (both open- and closed-structured), subtropical grasslands ( \pm trees) and closed-forests (rainforests) that have developed in the arid to the humid zones in warm temperate and subtropical climates.

These community-physiological processes will continue to operate to modify the structure, growth and biodiversity of these ecosystems during environmental impacts such as nutrient pollution, invasion of exotic species, overgrazing and climate change (Specht 1988b; Specht \& Specht 1995, 1999; Specht et al. 1974, 1995). 


\section{Acknowledgements}

The South African Meteorological Service provided long-term data on 102 climate stations throughout the country that was used in the estimation of Evaporative Coefficients.

\section{References}

Acocks, J. P. H. (1953, 1975). Veld Types of South Africa. Memoirs of the Botanical Survey of South Africa, 28, 1-192.

Anderson, J. M., Anderson, H. M., Archangelsky, S., Bamford, M., Chandra, S., Dettmann, M. E., Hill, R., McLoughlin, S., \& Rosler O. (1999) Patterns of Gondwana plant colonisation and diversification. Journal of African Earth Sciences, 27, 145-167.

Ashford, A. E., Ling-Lee, M., \& Chilvers, G. A. (1975). Polyphosphate in eucalypt mycorrhizae: A cytochemical demonstration. New Phytologist, 74, 447-453.

Bell, D. T., \& Watson, L. E. (1988). Species richness of plant communities in south-west Western Australia. In: Mediterranean-type Ecosystems. A Data Source Book. (Ed. R. L. Specht) p. 84. Kluwer Academic Publishers, Dordrecht, The Netherlands.

Bergh, N. G., Verboom, G. A., Rouget, M., \& Cowling, R. M. (2014). Vegetation types of the Greater Cape Floristic Region. In: Ecology and Evolution of Fynbos. Megadiversity in a Changing World. (Eds N. Allsopp, J. Colville \& A. G. Verboom). Oxford University Press, Oxford (in press).

Bigalke, R. C. (1979). Aspects of vertebrate life in fynbos, South Africa. In R. L. Specht (Ed.), Ecosystems of the World. Vol. 9A. Heathlands and Related Shrublands. Descriptive Studies. pp. 81-96. Elsevier, Amsterdam, The Netherlands.

Bond, W. (1983). On Alpha Diversity and the richness of the Cape flora: A study in southern Cape Fynbos. In F. J. Kruger, D. T. Mitchell, \& J. U. M. Jarvis (Eds.), Mediterranean-type Ecosystems. The Role of Nutrients (pp. 337-356). Springer-Verlag, Berlin, Germany.

Bond, W. (1988). Species richness of plant communities in the southern Cape Mountains, South Africa. In R. L. Specht (Ed.), Mediterranean-type Ecosystems. A Data Source Book. p. 90, Kluwer Academic Publishers, Dordrecht, The Netherlands.

Boucher, C., \& Moll, E. J. (1981). South African Mediterranean shrublands. In F. di Castri, D. W. Goodall \& R. L. Specht (Eds.), Ecosystems of the World. Vol. 11. Mediterranean-type Shrublands (pp. 233-248). Elsevier, Amsterdam, The Netherlands.

Braithwaite, R. W., Winter, J. W., Taylor, J. A., \& Parker, B. S. (1985). Patterns of diversity and structure of mammalian assemblages in the Australian tropics. Australian Mammalogist, $8,171-186$.

Braun-Blanquet, J. (1932). Plant Sociology. McGraw-Hill, New York, NY, USA.

Brownell, P. F., \& Crossland, C. J. (1972). The requirement for sodium as a micro-nutrient by species having the C4 dicarboxylic photosynthetic pathway. Plant Physiology, 49, 445-457. 
Burbidge, N. T. (1960). The phytogeography of the Australian region. Australian Journal of Botany, 22, 103-114.

Campbell, B. M., \& Moll, E. J. (1977). The forest communities of Table Mountain, South Africa. Vegetatio, 34, 105-115.

Carrodus, B. B., \& Specht, R. L. (1965). Factors affecting the relative distribution of Atriplex vesicaria and Kochia sedifolia (Chenopodiaceae) in the arid zone of South Australia. Australian Journal of Botany, 13, 419-433.

Clifford, H. T., \& Simon, B. K. (1981). The biogeography of Australian grasses. In: Ecological Biogeography of Australia. (Ed. A. Keast) pp. 537-554, Junk. The Hague, The Netherlands.

Coleman, R. G., \& Specht, R. L. (1981). Mineral nutrition of heathlands; The possible role of polyphosphate in the phosphorus economy of heathland species. pp. 197-207. In R. L. Specht (Ed.), Ecosystems of the Worlds. Vol. 9B. Heathlands and Related Shrublands. Analytical Studies. Elsevier, Amsterdam.

Cooper, K. H., \& Swart, W. (1992). Transkei Forest Survey. Wildlife Society Southern Africa, Conservation Division, 100 Brand Road, Durban, South Africa 4001. ISBN No. 0947058346.

Coupland, R. T. (Ed.) (1993). Ecosystems of the World. Vol 8B. Natural Grasslands. Eastern Hemisphere and Résumé. Elsevier, Amsterdam, The Netherlands.

Cowling, R. M. (1988). Species richness of plant communities in Cape Province, South Africa. In R. L. Specht (Ed.), Mediterranean-type Ecosystems. A Data Source Book (p. 91). Kluwer Academic Publishers, Dordrecht, The Netherlands.

Davies, J. G., \& Sim, A. H. (1931). The influence of frequency of cutting on the productivity, botanical and chemical composition, and the nutritive value of "natural" pastures in southern Australia. Council of Scientific and Industrial Research (Aust.) Pamphlet No. 18.

Davies, J. G., Scott, A. E., \& Fraser, K. M. (1934). Natural Pastures: Their Response to Superphosphate. Council of Scientific and Industrial Research (Aust.) Bulletin No. 83.

Deacon, H. J. (1983). The comparative evolution of Mediterranean-type ecosystems: A southern perspective. In: Mediterranean-type Ecosystems. The Role of Nutrients. (Eds F. J. Kruger, D. T. Mitchell and J. U. M. Jarvis) pp. 3-40. Springer-Verlag, Berlin, Germany.

Dettmann, M. E. (1999). Patterns of radiation and diversification of some Gondwanan angiosperm families. Journal of African Earth Sciences, 27, 60-61.

Di Castri, F., Goodall, D. W., \& Specht, R. L. (Eds.) (1981). Ecosystems of the World. Vol. 11. Mediterranean-type Shrublands. Elsevier, Amsterdam, The Netherlands.

Doley, D., \& Trivett, N. A. B. (1974). Effects of low water potentials on transpiration and photosynthesis in Mitchell grass (Astrebla lappacea). Australian Journal of Plant Physiology, $1,539-550$. 
Doley, D., Yates, D. J., \& Unwin, G. L. (1987). Photosynthesis in an Australian rainforest tree, Argyrodendron peralatum, during the rapid development and relief of water deficits in the dry season. Oecologia, 74, 441-449.

Edmonds, S. J., \& Specht, M. M. (1981). Dark Island heathland, South Australia: faunal rhythms. In: Ecosystems of the World. Vol. 9B. Heathlands and Related Shrublands. Analytical Studies. (Ed. R. L. Specht) pp. 15-28, Elsevier, Amsterdam, The Netherlands.

Evanari, M., Noy-Meir, I., \& Goodall, D. W. (Eds) (1986). Ecosystems of the World. Vol. 12B. Hot Deserts and Arid Shrublands. Elsevier, Amsterdam, The Netherlands.

Farquhar, G. D., \& Richards, R. A. (1984). Isotope composition of plant carbon correlates with water-use efficiency of wheat genotypes. Australian Journal of Plant Physiology, 11, 539-552.

Farquhar, G. D., \& Sharkey, T. D. (1982) Stomatal conductance and photosynthesis. Annual Review of Plant Physiology, 33, 317-345.

Fitzpatrick, E. A. (1963). Estimates of pan evaporation from mean maximum temperature and vapour pressure. Journal of Applied Meteorology, 2, 780-792.

George, A. S., Hopkins, A. J. M., \& Marchant, N. G. (1979). The heathlands of Western Australia. In Ecosystems of the World, Vol. 9A, Heathlands and Related Shrublands, Descriptive Studies (Ed. R. L. Specht) pp. 211-230, Elsevier, Amsterdam, The Netherlands.

George, A. S., Hopkins, A. J. M., \& Marchant, N. G. (1988). Species richness of heathlands in southwest Western Australia. In: Mediterranean-type Ecosystems. A Data Source Book. (Ed. R.L. Specht) p. 85, Kluwer Academic Publishers, Dordrecht, The Netherlands.

Gibbs Russell, G. E., Watson, L., Koekemoer, M., Smook, L., Barker, N., Anderson, H. M., \& Dallwitz, M. (1990). Grasses of Southern Africa. Memoirs of the Botanical Survey of South Africa, vol. 58, Pretoria, South Africa.

Goodall, D. W. (Gen. Ed.) (1977-2006) Ecosystems of the World. 30 Vols. Elsevier, Amsterdam, The Netherlands.

Groves, R. H. (1965). Growth of Themeda australis tussock grassland at St Albans, Victoria. Australian Journal of Botany, 13, 291-302.

Hatch, H. D., \& Slack, C. R. (1966). Photosynthesis by sugar cane - a new carboxylation reaction and the pathway of sugar formation. Biochemistry Journal, 101, 103-111.

Havel, J. J. (1975). Site vegetation mapping of the northern jarrah forests (Darling Range): I. Definition of site-vegetation types. II. Location and mapping of site-vegetation types. Western Australian Forestry Department Bulletin Nos. 86 \& 87.

Heddle, E. M. (1980). Effects of changes in soil moisture on the native vegetation of the northern Swan Coastal Plain, Western Australia. Western Australian Forestry Department Bulletin No. 92, 51 pp. 
Heddle, E. M., \& Specht, R. L. (1975). Dark Island heath (Ninety-Mile Plain, South Australia). 8. The effect of fertilizers on composition and growth, 1950-1972. Australian Journal of Botany, 23, 151-164.

Hegarty, E. E. (1990) Leaf life-span and leafing phenology of lianes and associated trees during a rainforest succession. Journal of Ecology, 78, 300-312.

Hopkins, B. (1955). The species-area relations of plant communities. Journal of Ecology, 43, 409-426.

Isbell, R. F., Reeve, R., \& Hutton, J. T. (1983). Salt and sodicity. In: Soils. An Australian Viewpoint.pp. 107-117. CSIRO Aust. -Academic Press, Sydney.

Jaccard, P. (1928). Die statistiche-floristische Methods als Grundlage der Pflanzensoziologie. Handbuch Biologisch Arbeitsmethoden, Abderhalden, 11(5), 165-202.

Jeffrey, D. W. (1964). The formation of polyphosphate in Banksia ornata, an Australian heath plant. Australian Journal of Biological Science, 17, 845-854.

Jeffrey, D. W. (1967). Phosphate nutrition of Australian heath plants. I. The importance of proteoid roots in Banksia (Proteaceae). Australian Journal of Botany, 15, 403-412.

Jeffrey, D. W. (1968). Phosphate nutrition of Australian heath plants. II. The formation of polyphosphate by five heath species. Australian Journal of Botany, 16, 603-613.

Jessop, J. P., \& Toelken, H. R. (Eds) (1986). Flora of South Australia. Part IV. Alismataceae-Orchidaceae. Fourth Edition. Government Printer, Adelaide, South Australia.

Johnson, L. A. S., \& Briggs, B. G. (1981). Three old southern families - Myrtaceae, Proteaceae and Restionaceae. In: Ecological Biogeography of Australia. (Ed. A. Keast) pp. 427-469, Junk. The Hague, The Netherlands.

Kikkawa, J., Ingram, G. I., \& Dwyer, P. D. (1979). The vertebrate fauna of Australian heathlands - An evolutionary perspective. In: Ecosystems of the World. Vol. 9A. Heathlands and Related Shrublands. Descriptive Studies. (Ed. R. L. Specht) pp. 231-280, Elsevier, Amsterdam, The Netherlands.

Killick, D. J. B. (1978). The Afro-alpine Region. In: Biogeography and Ecology of Southern Africa. (Ed. M. J. A. Werger) pp. 517-560, Junk Publishers, The Hague, The Netherlands.

Killick, D. J. B. (1979). African mountain heathlands. In: Ecosystems of the World. Vol. 9A. Heathlands and Related Shrublands. Descriptive Studies. (Ed. R. L. Specht) pp. 97-116, Elsevier, Amsterdam, The Netherlands.

Kruger, F. J. (1979). South African heathlands. In: Ecosystems of the World. Vol. 9A. Heathlands and Related Shrublands. Descriptive Studies. (Ed. R. L. Specht) pp. 19-80, Elsevier, Amsterdam, The Netherlands.

Kruger, F. J. (1981). Seasonal growth and flowering rhythms: South African heathlands. In: Ecosystems of the World. Vol. 9B. Heathlands and Related Shrubland. Analytical Studies. (Ed. 
R. L. Specht) pp. 1-4, Elsevier, Amsterdam, The Netherlands.

Kruger, F. J., Mitchell, D. T., \& Jarvis, J. U. M. (Eds) (1983). Mediterranean-Type Ecosystems. The Role of Nutrients. Springer-Verlag, Berlin, Germany.

Lambers, H., Cawthray, G. R., Giavalisco, P., Kuo, J., Laliberté, E., Pearse, S. J., Scheible, W-R., Stitt, M., Teste, F., \& Turner, B. L. (2012). Proteaceae from severely phosphorus-impoverished soils extensively replace phospholipids with galactolipids and sulpholipids during leaf development to achieve high photosynthetic phosphorus-use-efficiency. New Phytologist 196, 1098-1108.

Long, G. (1974). Diagnostic Phyto-Écologique et Amenagement du Territoire. Masson, Paris, France.

Marshall, J. K. (1971). Drag measurements in roughness arrays of varying density and distribution. Agricultural Meteorology 8, 269-192.

Martin, H. A., \& Specht, R. L. (1962). Are mesic communities less drought resistant? A study on moisture relationships in dry sclerophyll forest at Inglewood, South Australia. Australian Journal of Botany 10, 106-118.

McKenzie, B., Moll, E. J., \& Denman, S. (1990). The forests of the Swartkransberg, South Africa. Institut Mitteilung Allgemein Botanisch, Hamburg, 23, 119-128.

McNaughton, S. J. (1985). Interactive regulation of grass yield and chemical properties by defoliation, a salivary chemical and inorganic nutrition. Oecologia, 65, 478-486.

Mitchell, P. J., Veneklaas, E. J., Lambers, H., \& Burges, S. S. O. (2008). Using multiple trait associations to define hydraulic functional types in plant communities in south-western Australia. Oecologia, 158, 385-397.

Mittelheuser, Catherine J. (1977). Rapid ultrastructural recovery of water stressed leaf tissue. Zeitschrift für Pflanzenphysiologie, 82, 458-461.

Moisel, A., \& Moll, E. J. (1981). A Braun-Blanquet survey of the vegetation of the Welwitschia Plain. Dinteria ,15, 3-11.

Moll, E. J. (1974). A preliminary report on the Dwesa Forest Reserve, Transkei. Published by the Wildlife Society and the University of Cape Town. ISBN: 0949966215.

Moll, E. J., \& White, F. (1978). The Indian Ocean Coastal Belt. In: Biogeography and Ecology of Southern Africa. (Ed. M. J. A. Werger) pp. 561-598, Junk Publishers, The Hague, The Netherlands.

Moore, R. M. (1993). Grasslands of Australia. In: Ecosystems of the World. Vol. 8B. Natural Grasslands. Eastern Hemisphere and Résumé. (Ed. R. T. Coupland) pp. 315-360. Elsevier, Amsterdam, The Netherlands.

Myre, M. (1971). As pastagens da regiáo do Maputo. Memoire de Institute de Investigation Agronomique de Mocambique 3, 1-181. 
Ozanne, P. G., \& Specht, R. L. (1981). Mineral nutrition of heathlands: Phosphorus toxicity. In: Ecosystems of the World. Vol. 9B. Heathlands and Related Shrublands. Analytical Studies. (Ed. R. L. Specht) pp. 209-213, Elsevier, Amsterdam, The Netherlands.

Queensland Department of Science, Information Technology, Innovation and the Arts (2012) Land cover change in Queensland 2009-10: a Statewide Landcover and Trees Study (SLATS) report. DSITIA, Brisbane, Australia. <ISBN 976-1-7423-0948>

Robinson, E. R. (1977). A plant ecological study of the Namib Desert Park. Unpublished M.Sc. Thesis, University of Natal, Pietermaritzburg, South Africa.

Schmiedel, U., Dengler, J., Luther-Mosebach, J., Gröngröft, A., Muche, G., Petersen, A., Strohbach, B. J., \& Jürgens, N. (2010). Patterns and dynamics of vascular plant diversity along the BIOTA transects in southern Africa. In: Biodiversity in southern Africa. Vol. 2. Patterns and Processes at Regional Scale. (Eds U. Schmiedel \& N. Jürgens) pp. 118-135, Klaus Hess Publishers, Göttingen \& Windhoek.

Schodde, R. (1981). Bird communities of the Australian mallee: composition, derivation, distribution, structure and seasonal cycles. In: Ecosystems of the World. Vol. 11. Mediterranean-type Shrublands. (Eds F. di Castri, D. W. Goodall \& R. L. Specht) pp. 387-415, Elsevier, Amsterdam, The Netherlands.

Schultze, E. D., Williams, R. J., Farquhar. G. D., Schultze, W., Langridge, J., Miller, J. M., \& Walker, B. H. (1998). Carbon and nitrogen isotope discrimination and nitrogen nutrition of trees along a rainfall gradient in northern Australia. Australian Journal of Plant Physiology, $25,413-425$.

Simon B. K., \& Alfonso Y. (2011). AusGrass2. Retrieved from http://ausgrass2.myspecies.info/

Smith, A. G., \& Briden, J. C. (1977). Mesozoic and Cenozoic Palaeocontinental Maps. Cambridge University Press, Cambridge, England.

Specht, A. (1988). Resource Material. In: Big Scrub Conservation Strategy. Vol. 2. New South Wales National Parks and Wildlife Service, Sydney, Australia.

Specht, A., \& Specht, R. L. (1993). Species richness and canopy productivity of Australian plant communities. Biodiversity and Conservation, 2, 152-167.

Specht, A., \& Specht, R. L. (1994). Biodiversity of overstorey trees in relation to canopy productivity and stand density in the climatic gradient from warm temperate to tropical Australia. Biodiversity Letters, 2, 39-45.

Specht, A., \& Specht, R. L. (2001). Australia: biodiversity of ecosystems. In: Encyclopedia of Biodiversity (Ed. S. A. Levin) pp.307-324, Academic Press, San Diego, Calif., USA.

Specht, A., \& Specht, R. L. (2011). Australia: biodiversity of ecosystems. In Encyclopedia of Biodiversity. Second edition. (Ed. S. A. Levin) Elsevier, Kidlington, UK.

Specht, R. L. (1957a). Dark Island heath (Ninety-Mile Plain, South Australia). 4. Soil 
moisture patterns produced by rainfall interception and stem-flow. Australian Journal of Botany, 5, 137-150.

Specht, R. L. (1957b). Dark Island heath (Ninety-Mile Plain, South Australia). 5. The water relationships in heath vegetation and pastures on the Makin Sand. Australian Journal of Botany, 5, 151-172.

Specht, R. L. (1958a). Climate, geology, soils and plant ecology of the northern portion of Arnhem Land. In: Records of the American-Australian Scientific Expedition to Arnhem Land. Vol. 3. Botany and Plant Ecology. (Eds R. L. Specht \& C. P. Mountford) pp. 333-414. Melbourne University Press, Melbourne.

Specht, R. L. (1958b). Geographical relationships of the flora of Arnhem Land. In: Records of the American-Australian Scientific Expedition to Arnhem Land. Vol. 3. Botany and Plant Ecology. (Eds R. L. Specht \& C. P. Mountford) pp. 415-478. Melbourne University Press, Melbourne.

Specht, R. L. (1963). Dark Island heath (Ninety-Mile Plain, South Australia). 7. The effect of fertilizers on composition and growth, 1950-60. Australian Journal of Botany, 11, 67-94.

Specht, R. L. (1967). The photosynthesis of plant communities in relation to structure, physiology and environment. Photosynthetica, 1, 132-134.

Specht, R. L. (1970). Vegetation. In: The Australian Environment.( Fourth edition) (Ed. G. W. Leeper) (pp. 44-67). CSIRO \& Melbourne University Press, Melbourne, Australia.

Specht, R. L. (1972a). Water use by perennial, evergreen plant communities in Australia and Papua New Guinea. Australian Journal of Botany, 20, 273-299.

Specht, R. L. (1972b). The Vegetation of South Australia. Government Printer, Adelaide, South Australia.

Specht, R. L. (Ed.) (1979a). Ecosystems of the World. Vol. 9A. Heathlands and Related Shrublands. Descriptive Studies. Elsevier, Amsterdam, The Netherlands.

Specht, R. L. (1979b). The sclerophyllous (heath) vegetation of Australia: The eastern and central States. In: Ecosystems of the World. Vol. 9A. Heathlands and Related Shrublands. Descriptive Studies. (Ed. R. L. Specht) pp. 125-210, Elsevier, Amsterdam, The Netherlands.

Specht, R. L. (Ed.) (1981a). Ecosystems of the World. Vol. 9B. Heathlands and Related Shrublands. Analytical Studies. Elsevier, Amsterdam, The Netherlands.

Specht, R. L. (1981b). Mallee ecosystems in southern Australia. In: Ecosystems of the World. Vol. 11. Mediterranean-type Shrublands. (Eds F. di Castri, D.W. Goodall \& R.L. Specht) pp. 203-232, Elsevier, Amsterdam, The Netherlands.

Specht, R. L. (1981c). Growth indices - Their role in understanding the growth, structure and distribution of Australian vegetation. Oecologia, Berlin, 50, 347-356.

Specht, R. L. (1981d). Major vegetation formations in Australia. In: Ecological Biogeography 
of Australia. (Ed. A. Keast) pp. 163-298. Junk, The Hague, The Netherlands.

Specht, R. L. (1983). Foliage projective covers of overstorey and understorey strata of mature vegetation in Australia. Australian Journal of Ecology, 8, 433-439.

Specht, R. L. (Ed.) (1988a). Mediterranean-type Ecosystems. A Data Source Book. Kluwer Academic Publishers, Dordrecht, The Netherlands.

Specht, R. L. (1988b). Geosphere-biosphere interaction in terrestrial ecosystems. In: Global Change. (Ed. K. D. Cole) pp. 169-176. Australian Academy of Science, Canberra, Australia.

Specht, R. L. (1994). Species richness of vascular plants and vertebrates in relation to canopy productivity. In: Plant-Animal Interactions in Mediterranean-type Ecosystems (Eds M. Arianoutsou \& R. H. Groves) (pp. 15-24). Kluwer Scientific Publication, Dordrecht, The Netherlands.

Specht, R. L. (2000). Savanna woodland vegetation in the South East District of South Australia: The influence of evaporative aerodynamics on the foliage structure of the understorey invaded by introduced annuals. Austral Ecology, 25, 588-599.

Specht, R. L. (2007). Species richness of rainforest stands on non-serpentinite and serpentinite substrates in the Rockhampton-Marlborough area of Central Queensland. Proceedings of the Royal Society of Queensland, 113, 17-35.

Specht, R. L. (2011). Development of ecosystem research. International Scholarly Research Network ISRN Ecology, vol. 2011, Article ID 897578, 20 pages. http://dx.doi.org/ $10.5402 / 2011 / 897578$

Specht, R. L. (2012). Biodiversity of terrestrial ecosystems in tropical to temperate Australia. International Journal of Ecology, vol. 2012, Article ID359892, 15 pp. http://dx.doi.org/ $10.1155 / 2012 / 359892$

Specht, R. L., \& Brouwer, Y. M. (1975). Seasonal shoot growth of Eucalyptus spp. in the Brisbane area of Queensland (with notes on shoot growth and litter fall in other areas of Australia). Australian Journal of Botany, 23, 459-474.

Specht, R. L., \& Clifford, H. T. (1991). Plant invasion and soil seed banks. Control by water and nutrients. In: Biogeography of Mediterranean Invasions. (Eds R. H. Groves \& F. di Castri) pp. 191-204. Cambridge University Press, Cambridge, England.

Specht, R. L., \& Groves, R. H. (1966). A comparison of the phosphorus nutrition of Australian heath plants and introduced economic plants. Australian Journal of Botany, 14, 201-221.

Specht, R. L., \& Jones, R. (1971). A comparison of the water use by heath vegetation at Frankston, Victoria, and Dark Island Soak, South Australia. Australian Journal of Botany, 19, 311-326.

Specht, R. L., \& Moll, E. J. (1983). Mediterranean-type heathlands and sclerophyllous 
shrublands of the world: An overview. In: Mediterranean-type Ecosystems. The Role of Nutrients. (Eds F. J. Kruger, D. T. Mitchell and J. U. M. Jarvis) pp. 41-65, Springer-Verlag, Berlin, Germany.

Specht, R. L., \& Morgan, D. G. (1981). The balance between the foliage projective covers of overstorey and understorey strata in Australian vegetation. Australian Journal of Ecology, 6, 193-202.

Specht, R. L., \& Rayson, P. (1957). Dark Island heath (Ninety-Mile Plain, South Australia). 1. Definition of the ecosystem. Australian Journal of Botany, 5, 52-85.

Specht, R. L., \& Rundel, P. W. (1990). Sclerophylly and foliar nutrient status of mediterranean-climate plant communities in southern Australia. Australian Journal of Botany, $38,459-474$.

Specht, R. L., \& Specht, A. (1989a). Canopy structure in Eucalyptus-dominated communities in Australia along climatic gradients. Acta Oecologica, Oecologia Plantarum, 10,191-202.

Specht, R. L., \& Specht, A. (1989b). Species richness of overstorey strata in Australian plant communities - the influence of overstorey growth rates. Australian Journal of Botany, 37, 321-336.

Specht, R. L., \& Specht, A. (1989c). Species richness of sclerophyll (heathy) plant communities in Australia - the influence of overstorey cover. Australian Journal of Botany, 37, 337-350.

Specht, R. L., \& Specht, A. (1995). Global warming: Predicted effects on structure and species richness of Mediterranean ecosystems in southern Australia. In: Time Scales of Biological Responses to Water Constraints. (Eds J. Roy, J. Aronson \& F. di Castri) pp. 215-237. SPB Academic Publishing, Amsterdam, The Netherlands.

Specht, R. L., \& Specht, A. (1999). Australian Plant Communities. Dynamics of Structure, Growth and Biodiversity. Oxford University Press, Melbourne, Australia.

Specht, R. L., \& Specht, A. (2010). The ratio of foliar nitrogen to foliar phosphorus: a determinant of leaf attributes and height in life-forms of subtropical and tropical plant communities. Australian Journal of Botany, 58, 527-538.

Specht, R. L., \& Tyler, M. J. (2010). The species richness of vascular plants and amphibia in major plant communities in temperate to tropical Australia: Relationship with annual biomass production. International Journal of Ecology, vol. 2010, Article ID 635852, 17 pp. http://dx.doi.org/ 10.1155/2010/635852

Specht, R. L., \& Yates, D. J. (1990). Climatic control of structure and phenology of foliage shoots in dicotyledonous overstorey and understorey strata of subtropical plant communities. Acta Oecologia, 11, 215-233.

Specht, R. L., Rayson, P., \& Jackman, M. E. (1958). Dark Island heath (Ninety-Mile Plain, South Australia). 6. Pyric succession: Changes in composition, coverage, dry weight, and 
mineral nutrient status. Australian Journal of Botany, 6, 59-88.

Specht, R. L., Roe, E. M., \& Boughton, V. H. (Eds) (1974). Conservation of Major Plant Communities in Australia and Papua New Guinea. Australian Journal of Botany Supplement No. 7, Melbourne, Australia.

Specht, R. L., Rogers, R. W., \& Hopkins, A. J. M. (1981). Seasonal growth and flowering rhythms: Australian heathlands. In: Ecosystems of the World. Vol. 9B. Heathlands and Related Shrublands. Analytical Studies. (Ed. R. L. Specht) pp. 5-28, Elsevier, Amsterdam, The Netherlands.

Specht, R. L., Moll, E. J., Pressinger, F., \& Sommerville, J. (1983). Moisture regime and nutrient control of seasonal growth in Mediterranean ecosystems. In: Mediterranean-type Ecosystems. The Role of Nutrients. (Eds F. J. Kruger, D. T. Mitchell \& J. U. M. Jarvis) (Ecological Studies No. 43) Springer-Verlag, Berlin.

Specht, R. L., Grundy, R. I., Specht, A., \& Berliner, R. (1990) Species richness of plant communities: relationship with community growth and structure. Israel Journal of Botany, 39, 465-480.

Specht, R. L., Yates, D. J., Sommerville, J. E. M., \& Moll, E. J. (1991a). Foliage structure and shoot growth in heathlands in the Mediterranean-type climate of southern Australia and South Africa. Ecologia Mediterranea, 16, 195-207.

Specht, R. L., Clifford, H. T., Arianoutsou, M., Bird, L. H., Bolton, M. P., Forster, P. I., Grundy, R. I., Hegarty, E. E., \& Specht, A. (1991b). Structure, floristics and species richness of plant communities in southeast Queensland. Proceedings of the Royal Society of Queensland, 101, 27-78.

Specht, R. L., Dettmann, M. E., \& Jarzen, D. M. (1992). Community associations and structure in the Late Cretaceous vegetation of southeast Australasia and Antarctica. Palaeogeography, Palaeoclimatology, Palaeoecology, 94, 283-309.

Specht, R. L., Specht, A., Whelan, M. B., \& Hegarty, E. E. (1995). Conservation Atlas of Plant Communities in Australia. Southern Cross University, Lismore, New South Wales, Australia.

Stanley, T. D., \& Ross, E. M. (1983, 1986). Flora of South-Eastern Queensland. Vols I \& II. Queensland Department of Primary Industries, Brisbane, Australia.

Stewart, G. R., Gracia, C. A., Hegarty, E. E., \& Specht, R. L. (1990). Nitrate reductase activity and chlorophyll content in sun leaves of subtropical Australian closed-forest (rainforest) and open-forest communities. Oecologia, 82, 544-551.

Stock, W. D., \& Verboom, G. A. (2012). Phylogenetic ecology of foliar N and P concentrations and N:P ratios across mediterranean-type ecosystems. Global Ecology and Biogeography, 21, 1147-1156.

Stuwe, J., \& Parsons, R. F. (1977). Themeda australis grasslands on the Basalt Plains, 
Victoria: floristics and management effects. Australian Journal of Ecology, 2, 467-476.

Taylor, H. C. (1978). Capensis. In: Biogeography and Ecology of Southern Africa. (Ed. M. J. A. Werger) pp. 171-230, Junk Publishers, The Hague, The Netherlands.

Tiver, N. S., \& Crocker, R. L. (1951). The grasslands of south-eastern South Australia in relation to climate, soils and developmental history. Journal of the British Grassland Society, 6, 29-80.

Tucker, C. J. (1979). Red and photographic infrared linear combinations for monitoring vegetation. Remote Sensing of the Environment, 8, 127-150.

Vogel, J. C., Fuls, A., \& Ellis, R. P. (1978). The geographical distribution of Kranz grasses in South Africa. South African Journal of Science, 74, 209-215.

Wellman, P., \& McDougall, I. (1974). Caenozoic igneous activity in eastern Australia. Tectonophysics, 23, 49-65.

Werger, M. J. A. (1973). Phytosociology of the Upper Orange River Valley, South Africa. Dissertation, Nijmegen, The Netherlands.

Werger, M. J. A. (1978a). Biogeographical division of southern Africa. In: Biogeography and Ecology of Southern Africa. (Ed. M. J. A. Werger) pp. 145-170, Junk Publishers, The Hague, The Netherlands.

Werger, M. J. A. (1978b). The Karoo-Namib Region. In: Biogeography and Ecology of Southern Africa. (Ed. M. J. A. Werger) pp. 231-300, Junk Publishers, The Hague, The Netherlands.

Werger, M. J. A. (1986). The Karoo and southern Kalahari. In: Ecosystems of the World. Vol. 12B. Hot Deserts and Arid Shrublands. (Eds M. Evanari, I. Noy-Meir \& D. W. Goodall) pp. 283-359, Elsevier, Amsterdam, The Netherlands.

Werger, M. J. A., \& Coetzee, B. J. (1977). A phytosociological and phytogeographic study of Augrabies Falls National Park, South Africa. Koedoe 20.

Werger, M. J. A., \& Coetzee, B. J. (1978). The Sudano-Zambezian Region. In: Biogeography and Ecology of Southern Africa. (Ed. M. J. A. Werger) pp. 301-462, Junk Publishers, The Hague, The Netherlands.

Weston, P. H., \& Hill, R. S. (2013). Southern (Austral) Ecosystems. In: Encyclopedia of Biodiversity. Second edition. (Ed. S. A. Levin) Volume 6, pp. 612-619, Elsevier, Waltham, MA: Academic Press.

White, F. (1978). Afromontane Region. In: Biogeography and Ecology of Southern Africa. (Ed. M. J. A. Werger,) pp. 463-513, Junk Publishers, The Hague, The Netherlands.

Whittaker, R. H. (1972). Evolution and measurement of species diversity. Taxon, 21, 213-251.

Whittaker, R. H. (1977). Evolution of species diversity in land communities. Evolutionary 


\section{Macrothink}

Biology, 10, 1-67.

Whittaker, R. H., Niering, W. A., \& Crisp, M. D. (1979). Structure, pattern and diversity of a mallee community in New South Wales. Vegetatio, 39, 65-76.

\section{Copyright Disclaimer}

Copyright for this article is retained by the author(s), with first publication rights granted to the journal.

This is an open-access article distributed under the terms and conditions of the Creative Commons Attribution license (http://creativecommons.org/licenses/by/3.0/). 